University of Nebraska - Lincoln

DigitalCommons@University of Nebraska - Lincoln

2014

\title{
Evidence for Bluegill Spawning Plasticity Obtained by Disentangling Complex Factors Related to Recruitment
}

\author{
Mark A. Kaemingk \\ University of Nebraska - Lincoln, mkaemingk2@unl.edu \\ Kristopher J. Stahr \\ Oklahoma State University, kstahr@azgfd.gov \\ Jeffrey C. Jolley \\ US Fish \& Wildlife Service, jjolley@usgs.gov \\ Richard S. Holland \\ Nebraska Game \& Parks Commission \\ David W. Willis \\ South Dakota State University
}

Follow this and additional works at: https://digitalcommons.unl.edu/natrespapers

Part of the Natural Resources and Conservation Commons, Natural Resources Management and Policy Commons, and the Other Environmental Sciences Commons

Kaemingk, Mark A.; Stahr, Kristopher J.; Jolley, Jeffrey C.; Holland, Richard S.; and Willis, David W., "Evidence for Bluegill Spawning Plasticity Obtained by Disentangling Complex Factors Related to Recruitment" (2014). Papers in Natural Resources. 686.

https://digitalcommons.unl.edu/natrespapers/686

This Article is brought to you for free and open access by the Natural Resources, School of at DigitalCommons@University of Nebraska - Lincoln. It has been accepted for inclusion in Papers in Natural Resources by an authorized administrator of DigitalCommons@University of Nebraska - Lincoln. 


\title{
Evidence for bluegill spawning plasticity obtained by disentangling complex factors related to recruitment
}

\author{
Mark A. Kaemingk, Kristopher J. Stahr, Jeffrey C. Jolley, Richard S. Holland, and David W. Willis
}

\begin{abstract}
Fishes can exhibit many forms of plasticity to maximize fitness. However, limited information exists on the ability of freshwater fish to adjust spawning behavior and characteristics (e.g., timing, duration, magnitude of spawning events) to minimize mortality of recruits and ultimately maximize fitness. We wanted to test the life history hypothesis for bluegill (Lepomis macrochirus) (i.e., opportunistic strategy) utilizing existing literature and results from our study to further evaluate the potential for spawning plasticity in this species. Our objective was to identify bluegill recruitment bottlenecks (i.e., periods of high mortality) and factors associated with these events in a single lake during 7 consecutive years. Bluegills exhibited shorter spawning durations and fewer spawning pulses (i.e., peaks in larval production) compared with bluegill in previous studies. Late-hatched (compared with early-hatched) bluegills consistently contributed the most to the fall juvenile population; these recruitment patterns were primarily attributed to biotic drivers. Our study suggests that bluegill could exhibit spawning plasticity and extends our current understanding of adaptations that are potentially capable of increasing fitness for a freshwater fish species under a wide range of environmental conditions and uncertainty.

Résumé : Les poissons peuvent présenter différentes formes de plasticité leur permettant de maximiser leur aptitude. Peu de renseignements sont toutefois disponibles sur la capacité des poissons d'eau douce d'ajuster leur comportement de frai et les caractéristiques de ce dernier (p. ex. moment, durée, magnitude des évènements de frai) afin de minimiser la mortalité des recrues et, au final, maximiser leur aptitude. Nous voulions tester l'hypothèse du cycle biologique (c.à-d. stratégie opportuniste) pour le crapet arlequin (Lepomis macrochirus) à la lumière d'études existantes et des résultats de notre étude pour évaluer plus en détail le potentiel de plasticité du frai chez cette espèce. L'objectif consistait à cerner les goulots d'étranglement en ce qui concerne le recrutement de crapets arlequins (c.à-d. périodes de mortalité élevée) et les facteurs associés à ces évènements dans un seul lac pendant 7 années consécutives. Comparativement aux études antérieures, les crapets arlequins présentaient des durées de frai plus courtes et moins de pointes de frai (ou de production de larves). La contribution à la population juvénile automnale des crapets arlequins à éclosion tardive était uniformément plus importante que celle des individus à éclosion précoce, ces motifs de recrutement étant principalement attribuables à des facteurs biotiques. L'étude donne à penser que les crapets arlequins pourraient présenter une plasticité de frai et elle élargit la compréhension actuelle des adaptations pouvant potentiellement accroître l'aptitude d'une espèce de poissons dulcicoles pour un vaste éventail de conditions ambiantes et de niveaux d'incertitude. [Traduit par la Rédaction]
\end{abstract}

\section{Introduction}

Fishes exhibit life history characteristics and reproductive approaches that allow them to maximize their fitness under a range of environmental conditions or uncertainty (Van Winkle et al. 1993). Winemiller and Rose (1992) discussed these life history strategies and how each strategy is beneficial depending on the biotic and abiotic stressors encountered. However, each reproductive strategy within the set of life history end points (i.e., periodic, opportunistic, and equilibrium) also has associated trade-offs that do not allow maximum fitness under all environmental conditions (Reznick 1985; Paine 1990; Winemiller and Rose 1992; Winemiller 1992). While most species can be classified near one life history end point, some fishes exhibit intermediate combinations of these strategies (Winemiller and Rose 1992; Winemiller 2005; Olden et al. 2006).

Garvey et al. (2002) previously described bluegill (Lepomis macrochirus) as an opportunistic species given the protracted spawning nature and multiple pulses in reproduction typically observed for this species (Cargnelli and Gross 1996; Santucci and Wahl 2003; Jolley et al. 2009). In comparison to other freshwater fishes, bluegills are small, short-lived, and typically have high demographic resilience (i.e., consistent recruitment). These traits conform well to the opportunistic life history strategy (Winemiller 2005). However, in contrast with many other opportunistic species, bluegill reproductive output is much lower owing to the parental care provided by the male during the early development stages (Coleman et al. 1985; Gross and Sargent 1985; Garvey et al. 2002). The reproductive strategy for bluegill has often been described as a form of "bet hedging", most likely due to the inability to predict environmental conditions after spawning (Philippi and Seger 1989; Garvey et al. 2002) and the ability to develop eggs, or clutches of eggs, at different rates or periods during a single spawning season (Chvala 2000), similar to periodic type species on an interannual scale. Thus, a protracted spawning period with multiple reproductive pulses will likely result in some fitness each year, because the probability of at least some progeny

Received 25 May 2013. Accepted 12 September 2013.

Paper handled by Associate Editor Bror Jonsson.

M.A. Kaemingk and D.W. Willis. Department of Natural Resource Management, South Dakota State University, Brookings, SD 57007, USA.

K.J. Stahr. Department of Natural Resource Ecology and Management, Oklahoma State University, Stillwater, OK 74078, USA.

J.C. Jolley. United States Fish and Wildlife Service, Columbia River Fisheries Program Office, 1211 SE Cardinal Court, Vancouver, WA 98683, USA.

R.S. Holland. Nebraska Game and Parks Commission, P.O. Box 30370, Lincoln, NE 68701, USA.

Corresponding author: Mark A. Kaemingk (e-mail: mark.kaemingk@vuw.ac.nz). 
surviving to the adult life stage is much higher in bluegill compared with some other freshwater species, such as yellow perch (Perca flavescens: Kallemeyn 1987; Isermann and Willis 2008) and walleye (Sander vitreus: DeBoer et al. 2013), that spawn within a narrow temporal frame and have erratic recruitment. Therefore, bluegills also exhibit traits associated with the equilibrium strategy, with less variation in interannual juvenile survivorship and recruitment success compared with other freshwater fishes (Coble 1988).

Most studies have identified biotic factors as the largest component limiting overall bluegill fitness or recruitment compared with abiotic factors (albeit still influential). These factors typically include prey availability, predation, and interspecific or intraspecific competition (Beard 1982; Cargnelli and Gross 1996; Partridge and DeVries 1999; Santucci and Wahl 2003). This pattern is further supported by limited bluegill spawning or recruitment synchrony across multiple systems within a localized geographic area (Edwards et al. 2007; Jolley et al. 2009). Biotic drivers (e.g., food availability, species assemblage) are typically more predictable and divergent compared with abiotic drivers across systems (e.g., temperature, precipitation, wind; DeBoer et al. 2013).

Bluegill most likely adapted an opportunistic life history approach to maximize fitness while experiencing much interannual biotic (as opposed to abiotic) uncertainty, environmental stress, and a range of biotic factors, both in terms of level of magnitude and potentially a diverse array of factors each year. Thus, we hypothesize that factors affecting bluegill recruitment must vary across years, considering (i) the opportunistic strategy (smallbodied, short-lived, high demographic resilience, multiple spawning bouts or pulses and protracted spawning duration) and (ii) the parental investment and energy required for reproduction. For example, early-hatched bluegill could be favored one year and late-hatched individuals the next year, provided that different biotic factors are involved each year. Limited empirical information exists to support or test this idea owing to the lack of temporal replication and duration of existing bluegill recruitment studies (most studies $<3$ years).

Our global objective was to test the bluegill opportunistic life history strategy hypothesis and potentially refine our understanding of factors influencing population regulation of this species. Furthermore, we evaluated whether life history strategies are plastic at the population level on a nonevolutionary time scale. Within this context, we define spawning plasticity as the ability for individuals to substantially modify their life history strategy to account for changes in abiotic or biotic factors, ultimately leading to increased fitness at the population level (the scale of measurement for this study). For example, spawning plasticity would be evident if an individual female bluegill could adjust the number of spawning events (i.e., represented by pulses of egg or larval production at the population level), duration (i.e., time between the first and last spawning event), and the magnitude of spawning pulses (i.e., variability of egg or larval distribution and allocation) in response to abiotic or biotic stressors.

Our specific objective was to identify and relate factors associated with recruitment bottlenecks (i.e., periods of high mortality) in a single lake during 7 consecutive years. This approach would allow us to examine the bluegill opportunistic life history strategy hypothesis by accounting for both the factors (biotic versus abiotic) related to recruitment and which cohorts (i.e., early- versus late-hatched) were favored across a series of consecutive years. We hypothesized, based on the established empirical information for this species and the bluegill opportunistic life history strategy hypothesis, that interannual differences will exist for biotic factors regulating recruitment, ultimately leading to interannual variability in early- and late-hatched bluegill cohort survival. More specifically, to address these questions, we measured larval growth rates of two age classes (5-14 days old and 15-24 days old) of 10-day-old bluegill cohorts during 2004-2010 and related these patterns to abiotic and biotic factors. Similarly, juvenile growth rates of 10-day-old bluegill cohorts ( $>45$ days old) during 20062010 were also related to abiotic and biotic factors. Survival from the larval to the juvenile life stage was quantified and subsequently related to abiotic and biotic drivers. Finally, cohort contribution (early- versus late-hatched) of larval bluegill to the fall (i.e., prewinter) juvenile bluegill population was assessed to obtain additional information on recruitment bottlenecks across years.

\section{Methods}

\section{Study area}

Pelican Lake is a 332 ha, shallow (mean depth $1.3 \mathrm{~m}$ ) natural lake in the Sandhills region of north central Nebraska, USA, within the Valentine National Wildlife Refuge (Fig. $1 ; 42^{\circ} 31^{\prime} 37^{\prime \prime} \mathrm{N}, 100^{\circ} 40^{\prime} 20^{\prime \prime} \mathrm{W}$ ). Using the methods outlined by Paukert et al. (2002), emergent vegetation coverage during late July 2009 in Pelican Lake was 8.5\% for common reed (Phragmites australis), 15.5\% for softstem bulrush (Schoenoplectus tabernaemontani), and $7.0 \%$ for common cattail (Typha latifolia). The remaining portion of the lake was classified as submerged vegetation (9.9\%) and open water (59.1\% devoid of vegetation; Kaemingk and Willis 2012). The fish assemblage consists primarily of bluegill, yellow perch, largemouth bass (Micropterus salmoides), northern pike (Esox lucius), black bullhead (Ameiurus melas), common carp (Cyprinus carpio), and fathead minnow (Pimephales promelas).

\section{Larval and age-0 sampling and aging}

Larval (total length (TL) $<13 \mathrm{~mm}$ ) and age- 0 (TL $\leq 25 \mathrm{~mm}$ ) bluegill and yellow perch were sampled every 10 days from April through August or September 2004-2010 during daylight hours. Larval and age-0 bluegill and yellow perch densities were indexed using a surface trawl with a $0.76 \mathrm{~m}$ diameter opening and $0.1 \mathrm{~mm}$ mesh (bar measure) towed in large ellipses. Trawl duration was approximately 2-5 min at an estimated speed of $1.75 \mathrm{~m} \cdot \mathrm{s}^{-1}$. The lake was divided into 16 quadrats; 10 quadrats were randomly selected and trawled on each occasion. The amount of water volume sampled was calculated using a flowmeter (OceanTest Equipment, Inc., Fort Lauderdale, Florida, USA) mounted in the mouth of the trawl. All fishes were preserved in $70 \%$ ethanol and transported to the laboratory for identification to species (Auer 1982; Holland-Bartels et al. 1990) and further analysis. All fishes were enumerated, and up to 200 randomly selected fish per sample for each species were measured for TL to the nearest millimetre.

We collected, measured TL (mm), and aged a minimum of 30 larval bluegill (or three from each quadrat sampled) from each sampling date each year (except when fewer than 30 larval bluegill were collected). Aged larvae were randomly selected and closely mirrored the size of the larger sample for each sampling date (Pine and Allen 2001). A total of nine separate 10-day-old hatching cohorts were developed that accounted for all larval bluegill aged from 2004 through 2010. These nine hatching cohorts were further separated into an early-hatched (cohorts 1-4, beginning on 22 May and ending on 30 June) and late-hatched (cohorts 5-9, beginning on 1 July and ending on 19 August) period to further evaluate growth and mortality differences across cohorts and hatching periods. Peak larval bluegill densities typically occurred near 1 July, allowing for a natural separation between hatching periods (i.e., early versus late). During any given year, not all 10-day-old hatching cohorts were represented owing to differences in interannual hatching phenology. Sagittal otoliths of larval bluegill were aged by two independent readers using a compound microscope, and daily age estimates were averaged if they were within $10 \%$ of each other (Santucci and Wahl 2003). A third experienced reader was consulted if there was no agreement between readers, and the otolith was read in concert until consensus 
Fig. 1. A map of Nebraska, USA (A), and Pelican Lake (B).

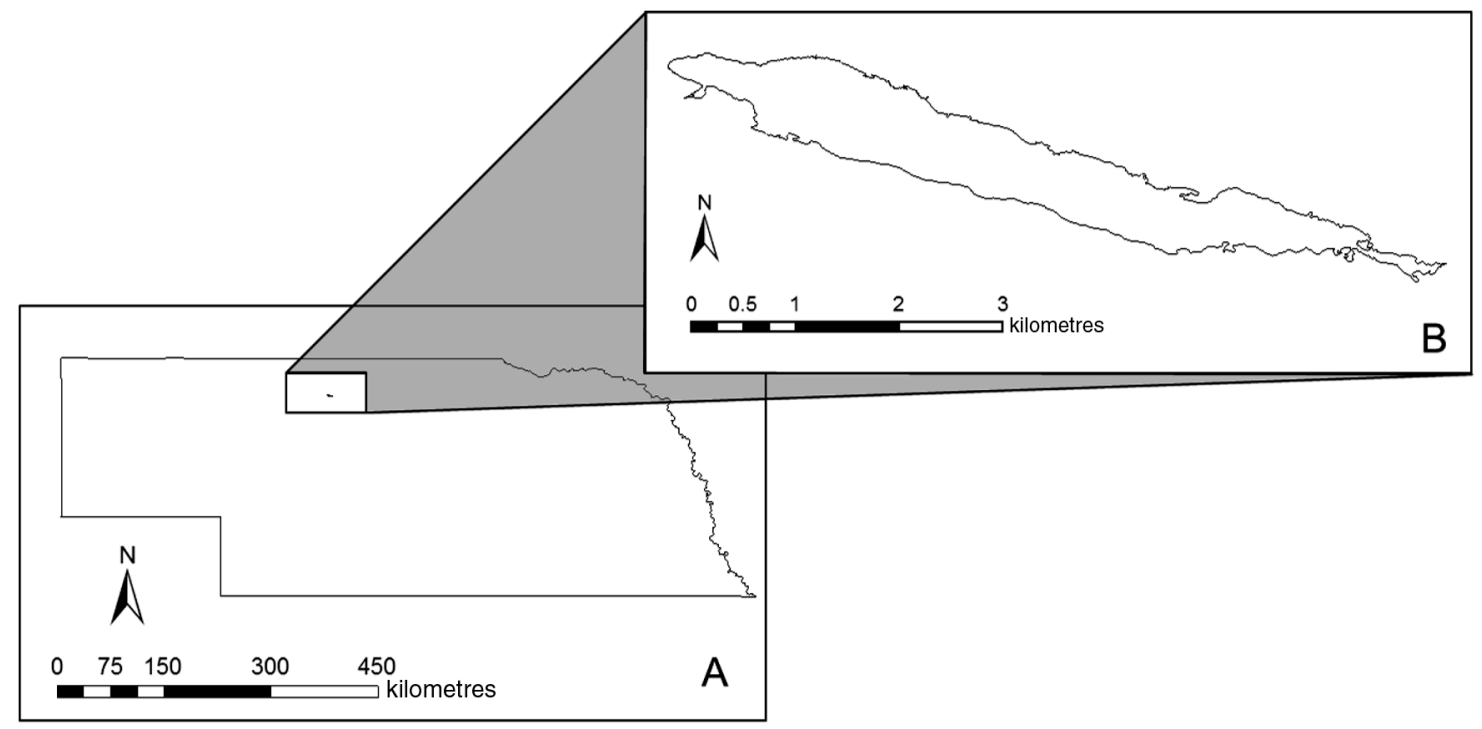

was reached. If all readers failed to reach an agreement, the otolith was removed from the dataset ( $5 \%$ were removed).

Larval bluegill cohort hatching distributions were based on the subsample of larval fish aged $(N=30)$ for each sampling date and extrapolated to account for all fish sampled. Therefore, larval cohort hatching distributions were corrected $\left(H_{i}\right)$ for each sampling date using the following formula: $H_{i}=\left(N_{i} / T\right) \times A$, where $i$ represents the 10-day-old hatching cohort (1-9), $N$ represents the total number of bluegill aged in cohort $i$, $T$ represents the total number of bluegill aged, and $A$ refers to the total number of bluegill sampled (Weber et al. 2011). Ultimately, all estimates were compiled within a given year to determine annual corrected hatching distributions.

\section{Juvenile sampling and aging}

Juvenile bluegill and yellow perch were collected once per year from Pelican Lake in August or September (i.e., fall) using cloverleaf traps that were placed in randomly chosen sites in nearshore areas of the lake in 1-2 $\mathrm{m}$ of water. Sampling occurred later in the season to encompass a majority of the limnetic (larval) to littoral (juveniles) movement of individuals. All fishes were preserved in $90 \%$ ethanol, returned to the laboratory, identified to species, and measured for TL (mm). Each three-lobed cloverleaf trap was constructed of galvanized $6.4 \mathrm{~mm}$ bar mesh, with three $12.7 \mathrm{~mm}$ wide openings between lobes to accommodate entrance of small bluegill and yellow perch (Brown and St. Sauver 2002; Kaemingk and Willis 2012). Each lobe was $50 \mathrm{~cm}$ in diameter with $41 \mathrm{~cm}$ height. Catch per unit effort (CPUE) was expressed as the mean number of juvenile fish captured per trap night. A total of 15 juvenile bluegills (if available) were aged per $5 \mathrm{~mm}$ TL category from 2006 to 2010. Aging methods for juvenile bluegill were similar to those for larval bluegill, except that 1500 grit sandpaper and water were used in some instances to better reveal the nucleus and provide more accurate age estimation. A total of $40(11 \%)$ aged juvenile bluegill were removed from the dataset because of reader disagreement from 2006 to 2010. Juvenile bluegill corrected hatching distributions followed the same approach previously described for larval bluegill.

\section{Independent variable field sampling}

Independent variables encompassing five broad categories (i.e., physical: Garvey et al. 2002; competition: Kaemingk et al. 2012; food availability: Partridge and DeVries 1999; predation: Santucci and Wahl 2003; and intrinsic: Cargnelli and Gross 1996) were sampled and used to explain patterns in bluegill growth and mor- tality (Table 1). Independent variables were selected based on previous studies relating to bluegill growth and mortality during the first year of life. Samples for each independent variable were collected from 10 (of 16 available) randomly selected lake quadrats from 2004 to 2008 and 5 quadrats in 2009 and 2010 (Kaemingk et al. 2011, 2012) every 10 days from late April to late August or early September unless otherwise noted.

We quantified phytoplankton biomass for each quadrat using chlorophyll $a$ estimated from integrated water samples $(N=2$ per quadrat) that were collected using a $2 \mathrm{~m}$ long tube sampler. Samples were strained through glass microfiber filters $(1 \mu \mathrm{m})$ in the field and extracted in the laboratory following the methods described by Lind (1985). Temperature data were recorded hourly from a HOBO pendant data logger (Onset Computer Corporation, Bourne, Massachusetts, USA) placed near the bottom of the lake. Water transparency was measured using a Secchi disk at each quadrat sampled. Lake vegetation coverage was assessed once during midsummer (late July or early August) following the methods outlined by Paukert et al. (2002) and separated into submerged only, emergent only, and total vegetation coverage. Largemouth bass were sampled with nighttime electrofishing in May each year using a Smith and Root model 5.0 GPP electrofishing system rated at $5000 \mathrm{~W}$ of output power and pulsed DC at 4-6 A and 60 pulses $\cdot \mathbf{s}^{-1}$.

Zooplankton were collected using a $2 \mathrm{~m}$ long tube sampler (Rabeni 1996). Two zooplankton samples were collected at each quadrat and filtered through a $65 \mu \mathrm{m}$ bar mesh net, stored in $90 \%$ ethanol, and then processed separately. Zooplankton were enumerated and identified to genus for cladocerans (e.g., Bosmina, Ceriodaphnia, Chydorus, Daphnia) and copepods (e.g., Cyclops, Diaptomus), and as copepod nauplii. Each sample was diluted with water to a measured volume of $30 \mathrm{~mL}$. Three subsamples were taken with a $5 \mathrm{~mL}$ Hensen-Stempel pipette and placed in a Ward counting wheel. Zooplankters were enumerated within each subsample, and the total number of zooplankton belonging to each taxon in a sample was calculated by dividing the number of organisms counted by the proportion of the sample volume processed. Density was calculated by multiplying the number of zooplankters of each taxon by the volume of the water filtered with the tube sampler. Up to 20 individuals per taxon were measured (nearest $0.01 \mathrm{~mm}$, TL) from each sample, and taxon-specific length - dry mass conversions were used to convert length to biomass $(\mathrm{g})$ (Cummins and Wuycheck 1971; Dumont et al. 1975; McCauley and Kalff 1981; Culver et al. 1985; Lynch et al. 1986). 
Table 1. List of candidate variables used to predict larval early- and late-hatched younger ("young”; 5- to 14-day-old) and older ("old”; 15- to 24-day-old) bluegill growth, early- and late-hatched juvenile bluegill growth (JG), and a bluegill survival index (SI).

\begin{tabular}{llc}
\hline $\begin{array}{l}\text { Candidate independent } \\
\text { variable }\end{array}$ & Description & $\begin{array}{c}\text { Response } \\
\text { variable(s) }\end{array}$ \\
\hline $\begin{array}{ll}\text { Physical } \\
\text { 1. Water transparency (WT) }\end{array}$ & Mean Secchi disk reading of 10-day intervals & Young, old, JG, SI \\
2. Temperature (TP) & Mean daily water temperature & Young, old, JG, SI \\
3. Phytoplankton (PHYT) & Mean chlorophyll $a$ density of 10-day intervals & Young, old, JG, SI \\
4. Submerged vegetation (SV) & Annual \% submerged vegetation lake coverage & JG, SI \\
5. Emergent vegetation (EV) & Annual \% emergent vegetation lake coverage & JG, SI \\
6. Total vegetation (TV) & Annual \% emergent and submerged vegetation lake coverage & JG, SI
\end{tabular}

\section{Competition}

1. Age-0 interspecific (YEPA)

2. Larval intraspecific (BLGL)

3. Age-0 intraspecific (BLGA)

4. Age-0 interspecific + intraspecific

(YEPA + BLGA)

5. Juvenile interspecific (YEPJ)

6. Juvenile intraspecific (BLGJ)

7. Juvenile interspecific + intraspecific (YEPJ + BLGJ)

Food availability

1. Total zooplankton (TZP)

2. Preferred zooplankton (PZP)

3. Total benthic invertebrates (TBI)

4. Preferred benthic invertebrates (PBI)

\section{Predation}

1. Largemouth bass (LMB)

\section{Intrinsic}

1. Larval growth rate (LGR)

2. Juvenile growth rate (JGR)
Mean 10-day trawling density of yellow perch $\leq 25 \mathrm{~mm}$ TL

Mean 10-day trawling density of bluegill $<13 \mathrm{~mm}$ TL

Mean 10-day trawling density of bluegill $\leq 25 \mathrm{~mm}$ TL

Mean 10-day trawling density of bluegill and yellow perch $\leq 25 \mathrm{~mm}$ TL

Annual fall cloverleaf catch per unit effort of yellow perch

Annual fall cloverleaf catch per unit effort of bluegill

Annual fall cloverleaf catch per unit effort of yellow perch and bluegill

Mean biomass of appropriately sized zooplankters during 10-day intervals

Mean biomass of appropriately sized copepod nauplii and Bosmina (larval and juvenile stages) and Chydorus (juvenile stage) during 10-day intervals

(Jolley et al. 2010; Kaemingk and Willis 2012)

Mean biomass of appropriately sized benthic invertebrates during 10-day intervals

Mean biomass of appropriately sized Chironomidae during 10-day intervals (Kaemingk and Willis 2012)

Annual May electrofishing catch per unit effort of largemouth bass (80-520 mm TL)

Young, old, JG, SI Young, old, JG, SI Young, old, JG, SI Young, old, JG, SI

JG, SI

$\mathrm{JG}, \mathrm{SI}$

JG, SI

Young, old, JG, SI Young, old, JG, SI

JG, SI

JG, SI

JG, SI

Early- or late-hatched younger or older larval bluegill daily growth rates Early- or late-hatched juvenile bluegill growth rates
SI

SI

Note: Please refer to text for more details on collection method specifics. BLG, bluegill; YEP, yellow perch.

Benthic macroinvertebrates were sampled using an Ekman grab sampler $\left(231 \mathrm{~cm}^{2}\right)$, strained through a $583 \mu \mathrm{m}$ bar mesh sieve in the field, and stored in $90 \%$ ethanol. Macroinvertebrates were identified to order, except for the order Diptera, which was identified to family and enumerated using a dissecting microscope in the laboratory. Up to 20 individuals of each taxon were measured (mm, TL), and taxon-specific length - dry mass conversions were used to convert length to biomass (g) (Smock 1980; Benke et al. 1999). Benthic macroinvertebrate biomass was calculated by multiplying the number of benthic macroinvertebrates belonging to each taxon by the area sampled with the Ekman grab and expressed as grams per square metre.

\section{Analyses}

\section{Growth rate}

Daily growth rates for larval and juvenile bluegill were estimated as (TL - 4.3)/age (days), where TL $(\mathrm{mm})$ represents the total length of fish at capture, 4.3 represents the total length at hatch (mm; Kim and Park 1987; Cargnelli and Gross 1996; Kaemingk unpublished data), and age represents the age of fish posthatch. Taubert and Coble (1977) reported that the first growth increment occurs at swim-up for bluegill; Garvey et al. (2002) confirmed this and reported that swim-up occurs approximately 3 days posthatch. Therefore, hatching date for individual bluegill was calculated by adding 3 days to the growth increment count. Two separate age classes were developed for larval bluegill to examine the effects of independent variables on growth, as factors influencing growth may differ as a function of age and size. The 10-day- old age class larval bluegill were between 5 and 14 days old (hereafter referred to as younger larvae), and the 20-day-old age class larval bluegill were between 15 and 24 days old (hereafter referred to as older larvae). Both age classes consisted of larval bluegill $<13 \mathrm{~mm}$ TL. Larval bluegills were then grouped, and mean growth rates were calculated according to year (2004-2010), date of collection ( $\sim 10$-day intervals), hatching cohorts (1-9), and age class (young or old). A minimum of three individuals was required for each grouping for subsequent analyses. These groupings allowed growth to be examined for larval fishes that experienced similar lake conditions and thus allowed further examination of factors (independent variables) that could explain growth patterns of the younger larvae (endogenous versus exogenous transitional feeding stage) and older bluegill larvae (Bunnell et al. 2003).

Independent variables used to explain growth patterns were selected from three broad categories (physical, competition, food availability) and transformed when necessary to meet the assumptions required for each statistical analysis. Physical variables included water transparency, temperature, phytoplankton density, and aquatic vegetation metrics (Table 1). Competition variables included metrics relating to the two most abundant limnetic species as larvae (bluegill and yellow perch) in Pelican Lake (Table 1). Two size classes (larval and age-0) were evaluated for both species, as densities typically decline after $13 \mathrm{~mm}$ TL (suggesting movement toward littoral habitats), but age-0 bluegill and yellow perch were still captured at sizes $\leq 25 \mathrm{~mm}$ TL with the larval trawl (Kaemingk et al. 2012). Additionally, competition for food availability between age- 0 bluegill and yellow perch has been 
previously reported (Kaemingk et al. 2012), but not at the larval stage. Food availability metrics included total zooplankton biomass that would be available for each age class, adjusted for gape size using the following formula (Bremigan and Stein 1994): gape $=-0.074+0.064(\mathrm{TL}, \mathrm{mm})$. Therefore, all available zooplankton biomass $\left(B_{a}\right)$ within the gape size for each age class was included in all analyses using the following formula (Bunnell et al. 2003): $B_{a}=\Sigma p_{\mathrm{i}}\left(A_{i}\right)\left(B_{i}\right)$, where $p_{\mathrm{i}}$ is the proportion of zooplankters in taxon $i$ that are less than or equal to the larval gape size, $A_{i}$ refers to the total zooplankton abundance (number $\cdot \mathrm{L}^{-1}$ ) for taxon $i$, and $B_{i}$ is the mean calculated biomass of zooplankters in taxon $i$ that are less than or equal to the larval gape size. Similarly, preferred available zooplankton biomass that included copepod nauplii and Bosmina was also included for each age-class growth analysis (Bunnell et al. 2003; Jolley et al. 2010).

Measurements of each independent variable were averaged across sampling dates that corresponded to the duration each age class of larval bluegill experienced in the lake from hatch date until capture date. For example, independent variables were averaged across three and four sampling dates for each cohort of the younger and older bluegill larvae, respectively. An information theoretic approach (Akaike's information criterion, AIC $_{c}$ : Burnham and Anderson 2002) was used to examine the influence of each independent variable on daily growth rates for larval bluegill age classes. This approach allowed multiple models to be evaluated and related to larval growth rate, while the traditional regression approach selects only one model and ignores parsimony (Burnham and Anderson 2002). The number of available independent variables (Table 1) used to predict cohort growth rates was reduced following this stepwise procedure for early- and late-hatched younger and older larval bluegill: (i) only one variable was retained when multiple variables were correlated (e.g., preferred versus total zooplankton biomass), thus minimizing multicollinearity among independent variables; (ii) remaining variables were related to growth rates using Pearson's correlation analyses; and (iii) the strongest relationship ( $r$ and $P$ value) between growth rate and one independent variable from each broad category (physical, competition, food availability) was selected for subsequent post hoc model selection. Thus, candidate models consisted of one independent variable from each broad category $(N=3)$, including more complex models with combinations of independent variables $(N=7)$ used to explain growth rates. Models with delta $\operatorname{AIC}_{\mathrm{c}}\left(\Delta_{i}\right)$ scores $\leq 2$ were considered to provide substantial support for explaining patterns relating to larval bluegill growth (Burnham and Anderson 2002). Additionally, the proportion of variance explained $\left(R^{2}\right)$ for each model was also included to evaluate each model.

Juvenile early- and late-hatched bluegill growth rates were also related to multiple independent variables using Pearson's correlation analysis. Juvenile bluegill growth rates $\left(\mathrm{mm} \cdot \mathrm{day}^{-1}\right)$ and independent variable calculations were estimated using the same procedure as for larval bluegill, but annual mean growth rates were calculated for early- and late-hatched fish $(N=5$ per hatch period; 2006-2010) across cohorts (1-4, early; 5-9, late) rather than for each cohort within a given year. A more conservative approach was used to evaluate factors influencing juvenile bluegill growth, because multiple independent variables were only measured once per year (i.e., aquatic vegetation; juvenile fish and largemouth bass relative abundance). Thus, overall sample size was reduced substantially to include these variables and also precluded the use of an information theoretic approach to examine larval growth rates. The same stepwise procedure used for larval growth analyses was used to evaluate juvenile growth patterns, excluding step 3. Analysis of covariance (ANCOVA) (Proc GLM, SAS Institute Inc. 2003) allowed for the evaluation of differences in growth rates between hatch periods (early versus late) across years for larval (younger and older) and juvenile bluegill, using individ- ual cohorts as the experimental unit. All analyses were deemed significant at $\alpha=0.10$ to guard against committing a type II error.

\section{Survival index}

A cohort survival index was calculated as $J_{i} / H_{i}$, where $i$ represents an individual hatching cohort (1-9) within a given year (2006-2010), $J_{i}$ is the proportion of juvenile bluegill collected in the fall sample, and $H_{i}$ is the proportion of larvae that hatched from cohort $i$ sampled during the summer. Therefore, index values $\approx 1$ indicate equal representation of juvenile survivors in the fall and those larvae hatching during the spawning season. Index values $<1$ or $>1$ indicate lower or higher than expected survival to the fall life stage, respectively. Calculated cohort survival indices from 2006 through 2010 were then related to independent variables previously used for growth analyses (Table 1) to evaluate mortality patterns between early- and late-hatched periods for bluegill ( $N=5$ per hatch period; 2006-2010). Additional independent variables included larval and juvenile growth rates for each respective juvenile and larval age-class (younger and older) hatch period. The same stepwise procedure used for the juvenile growth analyses was used to evaluate survival patterns. Thus, significant relationships with metrics measured at the larval stages and the survival index would suggest that most mortality occurred at the larval stage rather than during the transitional period between larval and juvenile life stages. In contrast, a strong relationship between the survival index and metrics measured during the juvenile life stage would suggest greater mortality after the larval stage and could be related in part to these metrics. Survival index differences between early- and late-hatched periods were evaluated using a Mann-Whitney $U$ test because of failure to meet parametric test assumptions.

\section{Results}

\section{Growth rate}

Growth rates for the younger bluegill larvae (5-14 days old) ranged from $0.16 \mathrm{~mm} \cdot \mathrm{day}^{-1}$ (cohort 2: 2010) to $0.52 \mathrm{~mm} \cdot \mathrm{day}^{-1}$ (cohort 4: 2005). Growth rates were similar across cohorts and hatch period for the younger larval bluegill during 2004-2010 (ANCOVA: $F_{[4,11]}=0.97, P=0.46$; Fig. 2). Bluegill growth rates for the older larvae (15-24 days old) ranged from $0.13 \mathrm{~mm} \cdot \mathrm{day}^{-1}$ (cohort 1: 2010) to $0.47 \mathrm{~mm} \cdot$ day $^{-1}$ (cohort 5: 2004). Growth rates differed across cohorts and hatch period for the older bluegill larvae during 2004-2010 (ANCOVA: $F_{[6,22]}=2.11, P=0.09$; Fig. 3). Older larval bluegill cohorts 2 and 3 exhibited slower growth rates compared with cohorts 5,6 , and 7 . Thus, late-hatched older bluegill larvae generally grew faster than early-hatched conspecifics. Juvenile bluegill growth rates ranged from $0.34 \mathrm{~mm} \cdot$ day $^{-1}$ (cohort 4: 2008) to $0.46 \mathrm{~mm} \cdot \mathrm{day}^{-1}$ (cohort 4: 2006) but did not differ across cohorts and hatch period during 2006-2010 (ANCOVA: $F_{[3,10]}=0.43, P=$ 0.74; Fig. 4).

The most supported model used to predict early-hatched younger larval bluegill growth included preferred zooplankton biomass (Table 2). Interestingly, larval bluegill growth was inversely related to preferred zooplankton biomass (Fig. 5). Other noteworthy models $\left(\Delta_{i}<2\right.$; Burnham and Anderson 2002) used to predict younger larval bluegill growth included $(i)$ a negative relationship with preferred zooplankton biomass and age-0 yellow perch density, (ii) a negative relationship with only age-0 yellow perch density, and (iii) a positive relationship with only water transparency (Table 2; Figs. 5 and 6).

Younger late-hatched larval bluegill growth was most related to water transparency (Table 2). Late-hatched bluegill growth increased with increasing water transparency. In addition, younger late-hatched larval bluegill growth decreased as a result of increasing densities of both age-0 bluegill and yellow perch densities. Total zooplankton biomass appeared unrelated to younger 
Fig. 2. Mean ( \pm standard error (SE)) cohort daily growth rates $\left(\mathrm{mm} \cdot \mathrm{day}^{-1}\right)$ for younger (5- to 14-day-old) larval bluegill from 2004 to 2010. Cohort refers to hatching dates as follows: (1) 22-31 May;

(2) 1-10 June; (3) 11-20 June; (4) 21-30 June; (5) 1-10 July; (6) 11-20 July; (7) 21-30 July. Dotted line indicates separation between hatching periods (left of line, early; right of line, late).

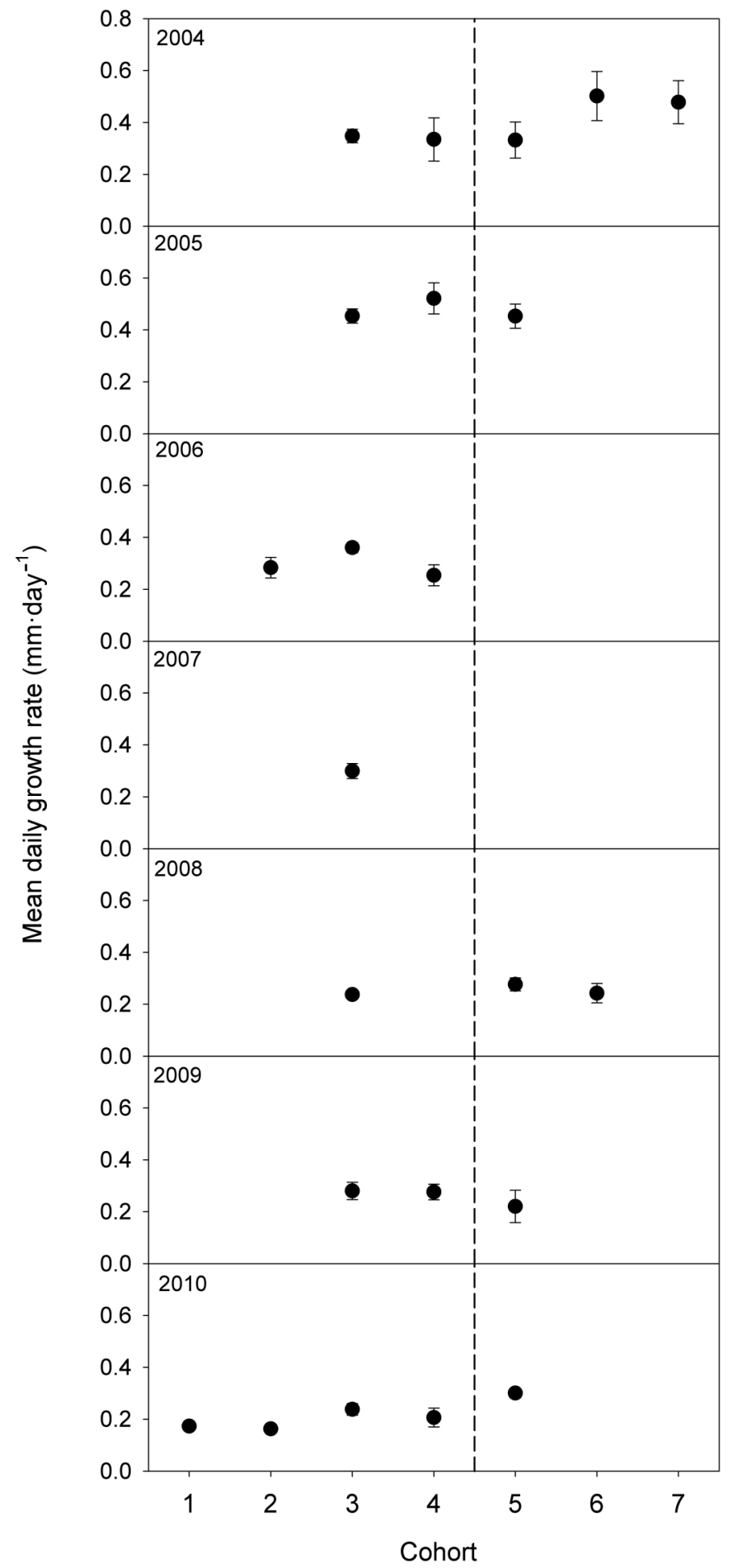

late-hatched larval bluegill growth and was not among the most supported models (Table 2).

Water temperature was positively related to older earlyhatched larval bluegill growth rate (Table 3). Additionally, water temperature and preferred zooplankton biomass were positively
Fig. 3. Mean $( \pm \mathrm{SE})$ cohort daily growth rates $\left(\mathrm{mm} \cdot \mathrm{day}^{-1}\right)$ for older (15- to 24-day-old) larval bluegill from 2004 to 2010. Cohort refers to hatching dates as follows: (1) 22-31 May; (2) 1-10 June; (3) 11-20 June; (4) 21-30 June; (5) 1-10 July; (6) 11-20 July; (7) 21-30 July; (8) 31 July 9 August; (9) 10-19 August. Dotted line indicates separation between hatching periods (left of line, early; right of line, late).

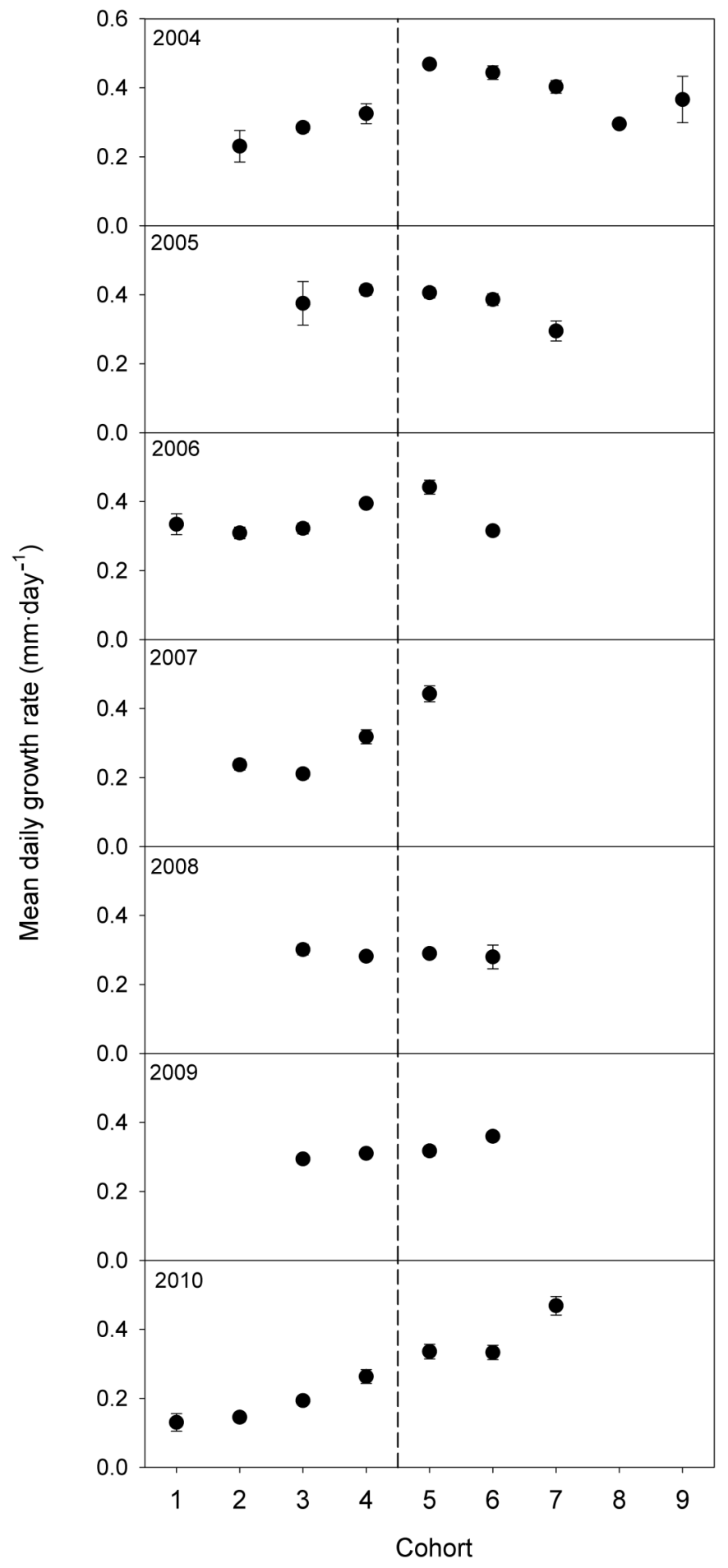

and negatively, respectively, related to older early-hatched larval bluegill growth. Other pertinent models used to explain earlyhatched bluegill growth included single-variable models of age-0 yellow perch density (negative relationship) and preferred zooplankton biomass (negative relationship). More complex models 
Fig. 4. Mean $( \pm \mathrm{SE})$ cohort daily growth rates $\left(\mathrm{mm} \cdot\right.$ day $\left.^{-1}\right)$ for juvenile bluegill from 2006 to 2010. Cohort refers to hatching dates as follows: (1) 22-31 May; (2) 1-10 June; (3) 11-20 June; (4) 21-30 June; (5) 1-10 July; (6) 11-20 July; (7) 21-30 July; (8) 31 July - 9 August; (9) 10-19 August. Dotted line indicates separation between hatching periods (left of line, early; right of line, late).

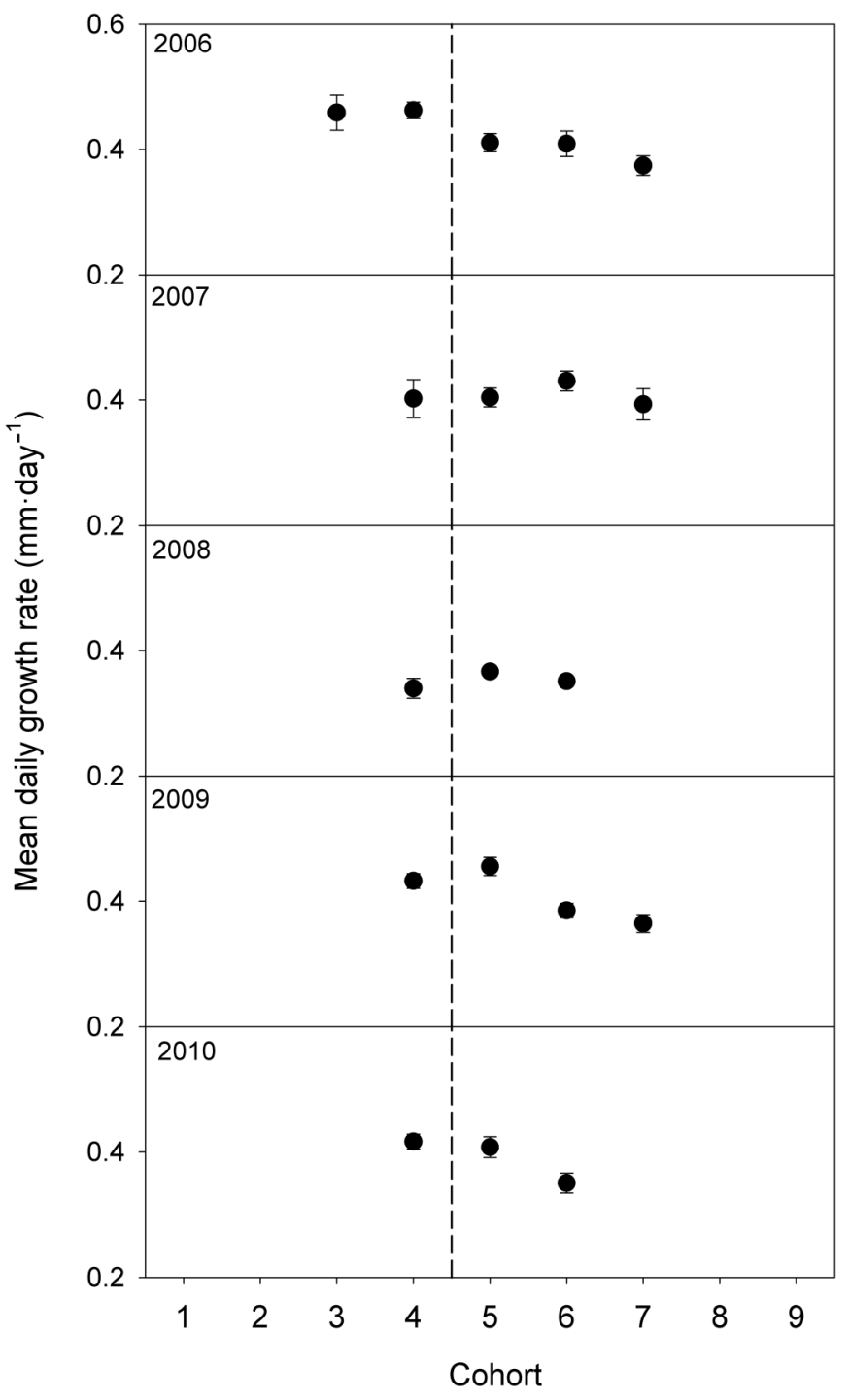

used to explain older early-hatched larval bluegill growth that included age-0 yellow perch density, preferred zooplankton biomass, and water temperature received very little support (Table 3).

Patterns of older late-hatched larval bluegill growth were best explained by a negative relationship with age-0 yellow perch and bluegill densities (Table 3). Single-variable models that included phytoplankton density (negative relationship) and preferred zooplankton biomass (negative relationship) also received some support to help explain growth patterns of older late-hatched larval bluegill. Other models that included two or more explanatory variables (i.e., age-0 yellow perch and bluegill density, preferred zooplankton biomass, phytoplankton density) received very little support and were unrelated to older late-hatched larval bluegill growth rates (Table 3).

Juvenile bluegill growth rates for both early-hatched and latehatched fish were unrelated to all independent variables measured (Table 4). Among the nonsignificant independent variables, phytoplankton density was most related to early-hatched juvenile bluegill growth $(r=0.68, P=0.21)$, whereas water transparency was
Table 2. Akaike's information criterion $\left(\mathrm{AIC}_{\mathrm{c}}\right.$ ) rankings of post hoc models to explain early- and late-hatched growth for younger (5- to 14-day-old) larval bluegill collected from Pelican Lake, Nebraska, during 2004-2010.

\begin{tabular}{lcrrrr}
\hline Model & $K$ & \multicolumn{1}{c}{$\mathrm{AIC}_{\mathrm{c}}$} & \multicolumn{1}{c}{$\Delta_{i}$} & $w_{i}$ & $R^{2}$ \\
\hline Early-hatched & & & & & \\
PZP & 3 & -26.61 & 0.00 & 0.33 & 0.46 \\
PZP, YEPA & 4 & -25.47 & 1.14 & 0.19 & 0.64 \\
YEPA & 3 & -25.02 & 1.59 & 0.15 & 0.32 \\
WT & 3 & -24.92 & 1.69 & 0.14 & 0.31 \\
PZP, WT & 4 & -24.49 & 2.13 & 0.12 & 0.59 \\
YEPA, WT & 4 & -22.52 & 4.09 & 0.04 & 0.44 \\
YEPA, WT, PZP & 5 & -21.66 & 4.95 & 0.03 & 0.69 \\
Late-hatched & & & & & \\
WT & 3 & -6.41 & 0.00 & 0.52 & 0.54 \\
YEPA+BLGA & 3 & -5.46 & 0.95 & 0.32 & 0.39 \\
TZP & 3 & -3.78 & 2.63 & 0.14 & 0.01 \\
TZP, WT & 4 & 1.92 & 8.33 & 0.01 & 0.65 \\
YEPA+BLGA, WT & 4 & 2.59 & 8.99 & 0.01 & 0.58 \\
YEPA+BLGA, TZP & 4 & 3.46 & 9.86 & 0.00 & 0.46 \\
YEPA+BLGA, WT, TZP & 5 & 19.38 & 25.79 & 0.00 & 0.76 \\
\hline \multicolumn{2}{l}{ N } &
\end{tabular}

Note: Results in the table include the number of parameters (K), Akaike information criterion corrected for small-sample bias $\left(\mathrm{AIC}_{\mathrm{c}}\right)$, differences in $\operatorname{AIC}_{\mathrm{c}}\left(\Delta_{i}\right)$, weights $\left(w_{i}\right)$, and the proportion of variance explained $\left(R^{2}\right)$ for each model. Abbreviations for independent variables are as follows: PZP, preferred zooplankton biomass; TZP, total zooplankton biomass; YEPA, age-0 yellow perch density; YEPA+BLGA, age-0 yellow perch and bluegill density; WT, water transparency.

Fig. 5. A three-dimensional graph depicting the relationship among preferred zooplankton biomass (copepod nauplii and Bosmina), water transparency (Secchi depth), and growth rates $\left(\mathrm{mm} \cdot \mathrm{day}^{-1}\right)$ of younger (5- to 14-day-old) early-hatched bluegill larvae.

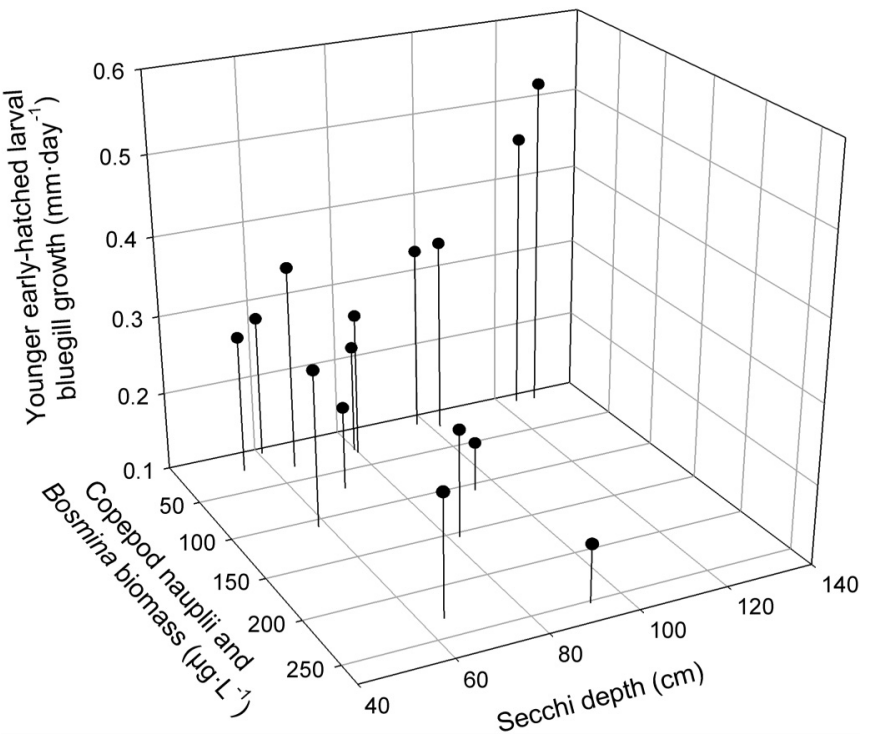

negatively related to late-hatched juvenile bluegill growth $(r=$ $-0.77, P=0.13$; Table 4).

\section{Survival index}

Survival indices $\left(\beta_{i}\right)$ ranged from 0 (most early-hatched cohorts, excluding cohort 4) to 32.17 (cohort 6, 2007; Fig. 7). Late-hatched bluegill experienced significantly higher survival compared with early-hatched bluegill in Pelican Lake during 2006-2010 (MannWhitney $U$ test: $P=0.0001$; Fig. 7). Early-hatched bluegill survival was positively related to age- 0 bluegill relative abundance $(r=$ $0.86, P=0.06$; Table 5). Alternatively, late-hatched bluegill survival was positively related to preferred zooplankton biomass $(r=0.90$, 
Fig. 6. A three-dimensional graph depicting the relationship among preferred zooplankton biomass (copepod nauplii and Bosmina), age-0 yellow perch density $\left(\right.$ no. $\left.\cdot 100 \mathrm{~m}^{-3}\right)$, and growth rates $\left(\mathrm{mm} \cdot \mathrm{day}^{-1}\right)$ of younger (5- to 14-day-old) early-hatched bluegill larvae.

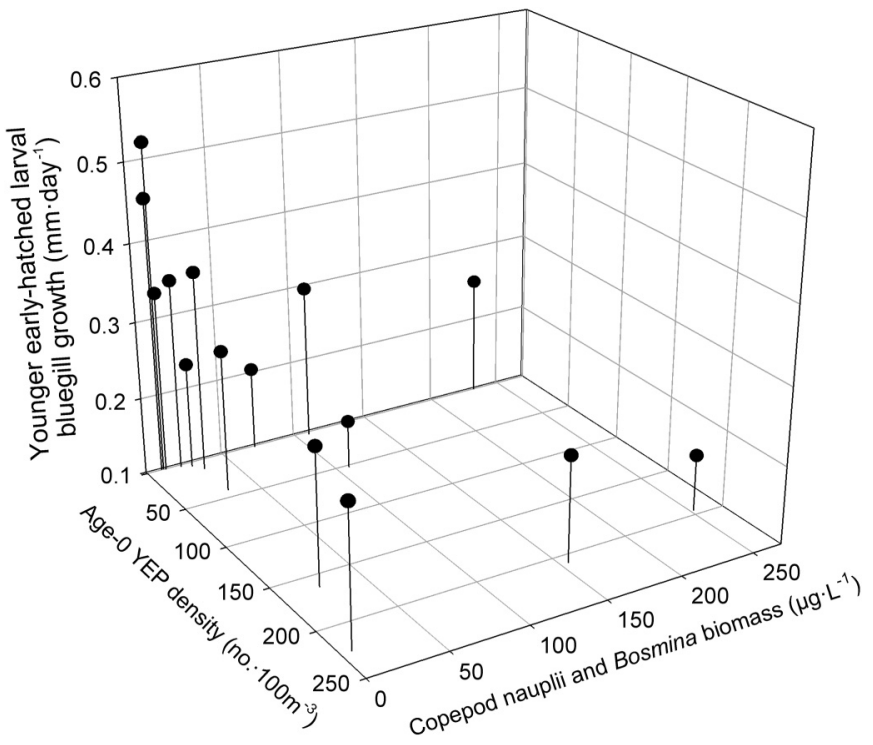

Table 3. Akaike's information criterion $\left(\mathrm{AIC}_{\mathrm{c}}\right)$ rankings of post hoc models to explain early- and late-hatched growth for older (15- to 24-day-old) larval bluegill collected from Pelican Lake, Nebraska, during 2004-2010.

\begin{tabular}{lccccc}
\hline Model & $K$ & $\mathrm{AIC}_{\mathrm{c}}$ & $\Delta_{i}$ & $w_{i}$ & $R^{2}$ \\
\hline Early-hatched & & & & & \\
TP & 3 & -40.12 & 0.00 & 0.29 & 0.23 \\
PZP, TP & 4 & -39.59 & 0.53 & 0.22 & 0.43 \\
YEPA & 3 & -39.38 & 0.73 & 0.20 & 0.16 \\
PZP & 3 & -38.45 & 1.67 & 0.12 & 0.07 \\
YEPA, TP & 4 & -37.38 & 2.74 & 0.07 & 0.27 \\
YEPA, PZP & 4 & -36.98 & 3.14 & 0.06 & 0.23 \\
YEPA, PZP, TP & 5 & -36.17 & 3.95 & 0.04 & 0.44 \\
Late-hatched & & & & & \\
YEPA+BLGA & 3 & -37.02 & 0.00 & 0.38 & 0.32 \\
PHYT & 3 & -35.67 & 1.35 & 0.19 & 0.27 \\
PZP & 3 & -35.63 & 1.39 & 0.19 & 0.19 \\
YEPA+BLGA, PHYT & 4 & -34.52 & 2.50 & 0.11 & 0.04 \\
YEPA+BLGA, PZP & 4 & -33.75 & 3.27 & 0.07 & 0.18 \\
PHYT, PZP & 4 & -32.39 & 4.63 & 0.04 & 0.03 \\
YEPA+BLGA, PHYT, PZP & 5 & -31.22 & 5.81 & 0.02 & 0.02 \\
\hline
\end{tabular}

Note: Results in the table include the number of parameters (K), Akaike information criterion corrected for small-sample bias ( $\mathrm{AIC}_{\mathrm{c}}$ ), differences in $\operatorname{AIC}_{\mathrm{c}}\left(\Delta_{i}\right)$, weights $\left(w_{i}\right)$, and the proportion of variance explained $\left(R^{2}\right)$ for each model. Abbreviations for independent variables are as follows: TP, water temperature; PZP, preferred zooplankton biomass; YEPA+BLGA, age-0 yellow perch and bluegill density; YEPA, age-0 yellow perch density; PHYT, phytoplankton density.

$P=0.04$; Table 5). All other independent variables measured were unrelated to the survival index for early- and late-hatched bluegill (Table 5).

\section{Cohort contribution}

Early-hatched bluegills were largely underrepresented compared with their late-hatched counterparts during the fall sampling period as juveniles across all years examined, despite most larval production occurring during May and June (early-hatched period) in most years (Fig. 8). The greatest representation during 2006-2010 typically occurred from cohorts 5 and 6, with few indi-
Table 4. Pearson's correlation coefficient $(r)$ and associated $P$ value for independent variables related to growth rates of early- and late-hatched juvenile bluegill collected from Pelican Lake, Nebraska, during 2006-2010.

\begin{tabular}{lrl}
\hline Variable & \multicolumn{1}{l}{$r$} & $P$ value \\
\hline Early-hatched & & \\
PZP & -0.16 & 0.79 \\
PBB & -0.62 & 0.27 \\
SV & 0.24 & 0.69 \\
YEPJ+BLGJ & 0.56 & 0.33 \\
YEPJ & 0.07 & 0.91 \\
PHYT & 0.68 & 0.21 \\
TP & -0.02 & 0.97 \\
Late-hatched & & \\
PZP & 0.63 & 0.26 \\
SV & -0.04 & 0.95 \\
WT & -0.77 & 0.13 \\
TP & 0.39 & 0.52 \\
PHYT & 0.39 & 0.51 \\
YEPJ+BLGJ & 0.53 & 0.36 \\
LMB & -0.43 & 0.47 \\
\hline
\end{tabular}

Note: Abbreviations for independent variables are as follows: PZP, preferred zooplankton; TZP, total zooplankton biomass; $\mathrm{PBB}$, preferred benthic invertebrate biomass; YEPJ, juvenile yellow perch density; YEPJ+BLGJ, juvenile yellow perch and bluegill relative abundance; $\mathrm{SV}$, submerged vegetation lake coverage; LMB, largemouth bass relative abundance; TP, water temperature; WT, water transparency; PHYT, phytoplankton density.

viduals surviving from cohorts 1-4 and moderate representation from cohorts 7, 8, and 9, when present (Fig. 8).

\section{Discussion}

We found evidence for bluegill spawning plasticity that is centralized around the opportunistic life history end point but is also plastic, taking on characteristics used to describe the other life history strategies (i.e., periodic and equilibrium; see Figs. 9 and 10). This conclusion was evidenced by similar biotic factors regulating recruitment each year, ultimately leading to higher latehatched bluegill cohort survival across all years studied. A relatively consistent pattern across years of comparatively short spawning durations (see Table 6) and a single spawning pulse (6 out of 7 years studied) apparently result in late-hatched bluegill recruiting to the Pelican Lake bluegill population each year. A truncated spawning duration and few pulsed reproductive events could maximize bluegill fitness in Pelican Lake while also minimizing the constraints caused by spawning due to parental energy costs. Therefore, bluegill may "optimize" reproductive output (i.e., more focused) to account for energy and reproductive constraints not typically observed in other opportunistic species.

Bluegill could be highly plastic with respect to life history strategies, often exhibiting components or traits of all (or combinations thereof) three strategies depending on system-specific environmental variation, resource availability at the early life stage, and environmental stress (most often in the form of biotic versus abiotic). Essentially, an individual bluegill may demonstrate some level of spawning plasticity and move from the opportunistic end point toward the periodic and equilibrium end points (Fig. 9). Bluegill reproductive efforts, such as spawning duration, the number of pulsed spawning events, and distribution or allocation of eggs within a spawning season, could reflect the degree of environmental uncertainty and stress (Fig. 10). For example, high environmental uncertainty and stress (as opposed to low) would be depicted by high numbers (both in number of species and population size) of competitors, increased predation pressure, limited food availability, etc. Collectively, individual spawning behaviors 
Fig. 7. Cohort survival indices for larval bluegill from 2006 to 2010, with cohorts that were present as larvae highlighted. Cohort refers to hatching dates as follows: (1) 22-31 May; (2) 1-10 June; (3) 11-20 June; (4) 21-30 June; (5) 1-10 July; (6) 11-20 July; (7) 21-30 July; (8) 31 July 9 August; (9) 10-19 August. Vertical dotted line indicates separation between hatching periods (left of line, early; right of line, late), and horizontal solid line represents equal representation between larval and juvenile survivors.

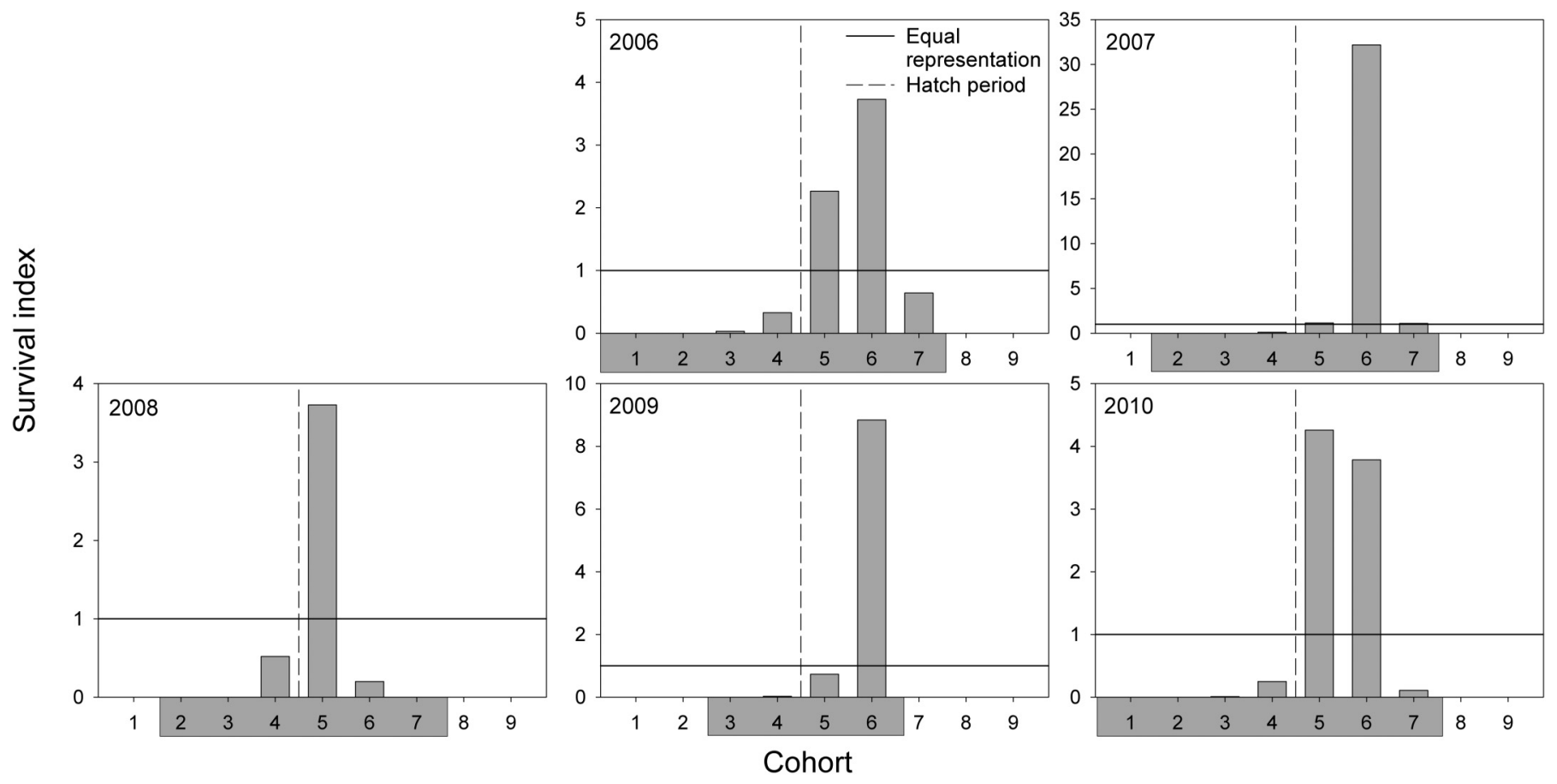

Table 5. Pearson's correlation coefficient $(r)$ and associated $P$ value for independent variables related to a survival index $\left(\beta_{i}\right)$ of early- and latehatched bluegill collected from Pelican Lake, Nebraska, during 2006-2010.

\begin{tabular}{lrl}
\hline Variable & \multicolumn{1}{r}{$r$} & P value \\
\hline Early-hatched & & \\
PZP & -0.30 & 0.62 \\
BLGA & 0.86 & 0.06 \\
SV & 0.47 & 0.42 \\
YEPJ & -0.06 & 0.92 \\
WT & 0.70 & 0.19 \\
PHYT & -0.10 & 0.88 \\
TP & -0.41 & 0.50 \\
LMB & 0.32 & 0.60 \\
Late-hatched & & \\
LGII & 0.66 & 0.22 \\
LJG & 0.71 & 0.18 \\
PZP & 0.90 & 0.04 \\
TP & 0.69 & 0.19 \\
PHYT & -0.03 & 0.96 \\
YEPA+BLGA & -0.63 & 0.26 \\
LMB & -0.19 & 0.76 \\
YEPJ+BLGJ & -0.00 & 0.99 \\
\hline \multicolumn{1}{l}{ NOt Abb }
\end{tabular}

Note: Abbreviations for independent variables are as follows: PZP, preferred zooplankton; YEPJ, juvenile yellow perch relative abundance; YEPA+BLGA, age-0 yellow perch and bluegill density; BLGA, age-0 bluegill density; SV, submerged vegetation lake coverage; LMB, largemouth bass relative abundance; TP, water temperature; WT, water transparency; PHYT, phytoplankton density; LGII, older late-hatched bluegill larval growth rate; LJG, latehatched juvenile bluegill growth rate; YEPJ+BLGJ, juvenile yellow perch and bluegill relative abundance. should result in bluegill populations that exhibit longer spawning durations, more pulsed spawning events, and highly variable distribution or allocation of eggs within years where environmental conditions are less predictable; likewise, bluegill populations should have shorter spawning durations, fewer pulsed spawning events, and less variable distribution or allocation of eggs within years where environmental conditions are more predictable and less stressful.

If individual bluegill are able to adapt to certain environments and develop a plastic spawning strategy to account for biotic (and potentially abiotic) uncertainty, we would expect single populations that experience greater environmental uncertainty and stress to exhibit multiple spawning pulses. For example, both bluegill recruitment studies in Lake Opinicon, Ontario, documented two pulsed spawning events (Cargnelli and Gross 1996; Garvey et al. 2002), suggesting that reproductive output was not especially focused to a large degree. Multiple spawning bouts would likely occur in systems such as that in Lake Opinicon, where more environmental uncertainty exists for enhancing fitness for bluegill compared with other systems in the same geographic area that may be more predictable. Both studies identified differential cohort survival during both years, potentially because of differences in interannual environmental uncertainty and stress.

The bluegill studies in Lake Opinicon, Ontario, interestingly identified a range in spawning duration (34-61 days) between studies despite the short growing season in that region (Cargnelli and Gross 1996; Garvey et al. 2002), which may further suggest that spawning plasticity could vary within a single population, depending on interannual biotic conditions. An additional example comes from the 271 ha Lake Mitchell in South Dakota, where a single, shorter spawning pulse was observed in 2005 followed by three prominent, longer spawning pulses in 2006 (Jolley et al. 2009). Relative abundances of most fish populations in Lake Mitchell remained unchanged during both years of sampling, with the exception of a substantial increase in both black crappie 
Fig. 8. Larval and juvenile bluegill survivors and their corrected hatching distributions standardized within each year as proportions (scaled to 1). Cohort refers to hatching dates as follows: (1) 22-31 May; (2) 1-10 June; (3) 11-20 June; (4) 21-30 June; (5) 1-10 July; (6) 11-20 July; (7) 21-30 July; (8) 31 July - 9 August; (9) 10-19 August. Dotted line indicates separation between hatching periods (left of line, early; right of line, late).

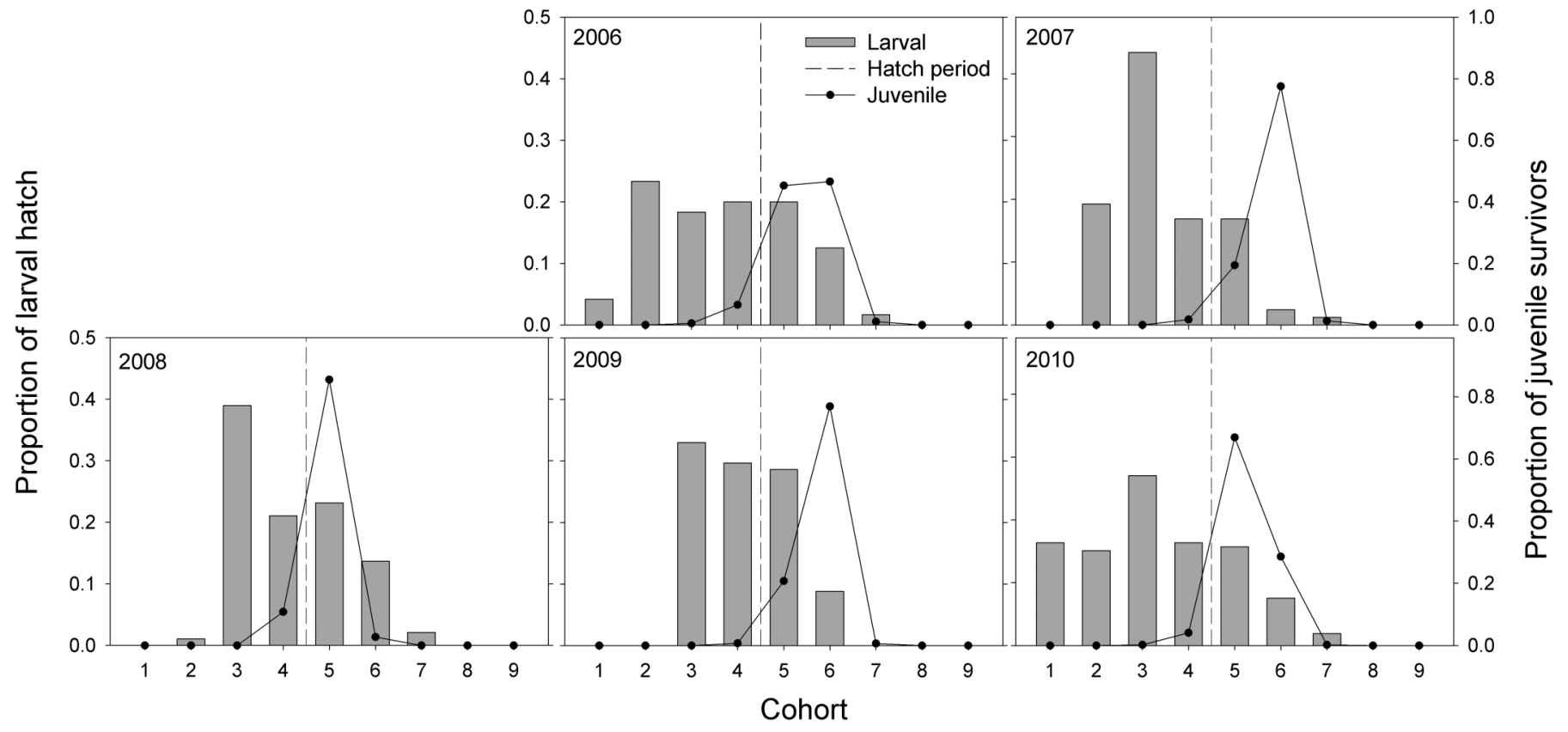

Table 6. A literature review of spawning pulses and duration across multiple different lakes.

\begin{tabular}{llll}
\hline Study & Lake & $\begin{array}{l}\text { Spawning pulses } \\
\text { (no.·year }{ }^{-1}\end{array}$ & $\begin{array}{l}\text { Spawning } \\
\text { duration (days) }\end{array}$ \\
\hline Cargnelli and Gross 1996 & Lake Opinicon; Ont., Canada & 2 & 34 \\
Garvey et al. 2002 & Lake Opinicon; Ont., Canada & 2 & $61^{*}$ \\
Partridge and DeVries 1999 & Pond S-3; Auburn; Ala., USA & 2 & $200^{*}$ \\
Partridge and DeVries 1999 & Pond S-8; Auburn; Ala., USA & 4 & $270^{*}$ \\
Jolley et al. 2009 & Lake Alvin; S.D., USA & 1,2 & $51-55$ \\
Jolley et al. 2009 & Lake Louise; S.D., USA & 1,1 & $8-42^{*}$ \\
Jolley et al. 2009 & Lake Marindahl; S.D., USA & 1,1 & $38-51$ \\
Jolley et al. 2009 & Lake Mitchell; S.D., USA & 1,3 & $71-77$ \\
Santucci and Wahl 2003 & Ridge Lake; Ill., USA & $3,2,3$ & $87-108$ \\
Chvala 2000 & Cozad Lake; Neb., USA & 2 & 49 \\
Beard 1982 & Camp Lake; Wisc., USA & $4,5,7,11$ & $37-112(59)$ \\
Beard 1982 & Lameraeu Lake; Wisc., USA & $6,9,7,6$ & $50-68(58)$ \\
Beard 1982 & Nancy Lake; Wisc., USA & $4,5,7,8$ & $31-59(50)$ \\
Kaemingk et al. (this study) & Pelican Lake; Neb., USA & $2,1,1,1,1,1,1$ & $42-77(56)$ \\
\hline
\end{tabular}

Note: Spawning pulses refer to peaks in larval abundance during a single year where larval densities exceed both the previous and subsequent sampling events (typically recorded on one sampling date), except for the Wisconsin study (Beard 1982), which used the egg and yolk-sac fry life stages. Spawning duration (sample means for studies $>2$ years are reported, if available, in parentheses) is the length, in days, of the spawning season and is estimated by subtracting the hatching date of the youngest larval fish from the oldest larval fish captured within a sampling year.

*Studies where larval bluegill were not aged or age-specific hatch dates were not reported; in these instances, estimates of days between first and last sampling dates where larvae are captured were provided.

(Pomoxis nigromaculatus) and bluegill numbers compared with the 10-year sampling mean (SDGFP 2011). Intraspecific and interspecific (i.e., black crappie; Seaburg and Moyle 1964) competition was greater in 2006 than in 2005 and may partially explain the longer spawning duration and multiple spawning bouts for bluegills that was observed in 2006. Increased spawning variability among individuals may result in longer population-level spawning durations to maximize the temporal dimension and increase the chances of successful recruitment each year, especially when the magnitude of environmental uncertainty is enhanced.

A spatial examination of the bluegill spawning plasticity hypothesis should also demonstrate that multiple reproductive strategies can occur within a localized geographic area (in contrast with a lati- tudinal gradient to explain reproductive strategies; Jolley et al. 2009), assuming that some systems are more or less predictable and stressful in some years than others with respect to factors influencing bluegill recruitment. Partridge and DeVries (1999) extensively studied bluegill recruitment in two Alabama ponds within the same vicinity and identified multiple pulsed spawning events and a slightly longer spawning duration in one pond compared with another pond that only had one pulsed spawning event during the same year. Interestingly, the pond that experienced a longer spawning duration and multiple pulsed spawning events also contained gizzard shad (Dorosoma cepedianum) and higher densities of largemouth bass (Micropterus salmoides), both of which have often been related to bluegill recruitment in other systems (Gabelhouse 1987; DeVries and 
Fig. 9. Figure modified from Winemiller and Rose (1992), and used in Winemiller (1995), illustrating a triangular life history model for bluegill (shaded area). Bluegills (similar to other fishes) are constrained by generation time and fecundity in an attempt to maximize juvenile survivorship given a range of environmental gradients. Essentially, bluegill populations could theoretically be placed anywhere within the shaded area, dependent on environmental conditions - moving toward or away from the periodic and equilibrium end points but primarily situated near the opportunistic end point. Lakes where bluegill recruitment was studied for 2 or more years (Table 6) are placed within the shaded area to demonstrate spawning plasticity that is dependent on environmental predictability and stress. Lake Mitchell (LMi) and Lake Opinicon (LO) tend toward the periodic strategy because of potential broad-scale interannual variation in environmental conditions that result in contrasting spawning pulses across years or differential cohort survival (i.e., early versus late hatching), respectively. Lake Louise (LL), Lake Marindahl (LMa), and Pelican Lake (PL) tend toward the equilibrium strategy because of potential low variation in interannual habitat quality and strong indirect or direct biotic conditions that result in similar interannual spawning pulses. The Wisconsin lakes (WI; Beard 1982) and Ridge Lake (RL) are situated near the opportunistic end point because of potential stochastic environmental conditions that are unpredictable and result in multiple spawning pulses each year and interannual differences in the number of spawning pulses each year. Finally, Lake Alvin (LA) is positioned somewhere intermediate to all other lakes.

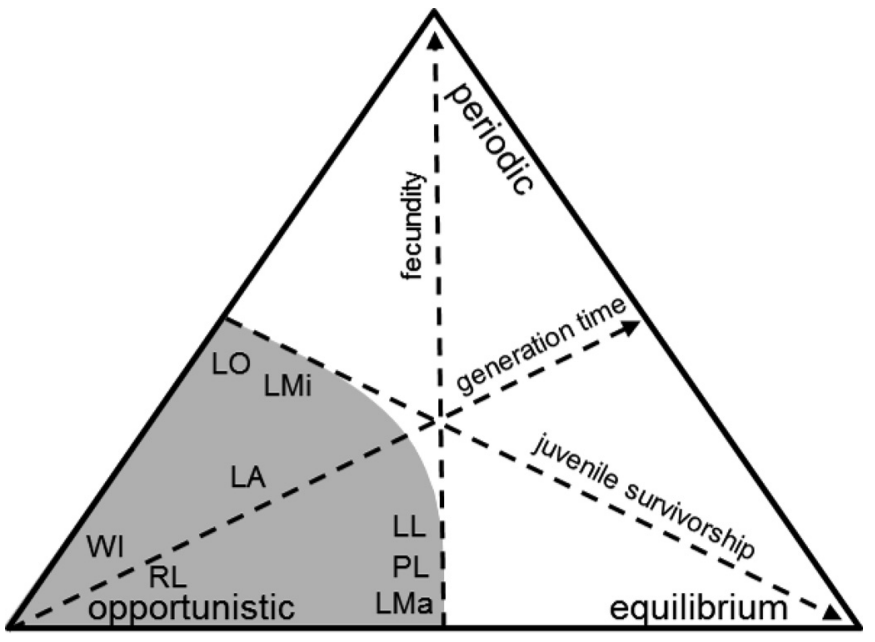

Stein 1992; Garvey and Stein 1998; Schneider 1999; Santucci and Wahl 2003; Shoup and Wahl 2008). Similarly, single or multiple spawning pulses and a range of spawning durations were identified across four eastern South Dakota impoundments for bluegill (Jolley et al. 2009). Chvala (2000) identified two Nebraska Sandhill lakes that experienced divergent spawning characteristics, with Cozad Lake bluegill larvae appearing 1 month earlier than Pelican Lake and having two spawning pulses compared with one pulsed spawning event in Pelican Lake (same lake as in our current study). Green sunfish (Lepomis cyanellus) and black crappie were present in Cozad Lake and not in Pelican Lake; both species can compete with bluegill for available resources (Seaburg and Moyle 1964; Werner and Hall 1977, 1979). Cozad Lake was also typified as a high-density Lepomis spp. lake because of a high abundance of bluegill $\times$ green sunfish hybrids. Bluegills in Cozad Lake exhibited slow growth rates compared with rates in other Sandhill lakes presumably as a result of higher interspecific and intraspecific competition for food resources (Olson et al. 2003). We also documented a more truncated spawning duration and mostly single spawning pulses in Pelican Lake from 2004 to 2010 compared with
Fig. 10. Schematic diagram demonstrating bluegill spawning plasticity, which is governed by (i) coarse physiological (e.g., system productivity, food availability) and latitudinal filters (e.g., temperature, duration of growing season) and (ii) fine physiological and latitudinal filters. Within these fine physiological and latitudinal filters, bluegill populations could exhibit different spawning characteristics related to spawning duration, the number of pulsed spawning events, and variability in the distribution or allocation of eggs during a single spawning season to maximize fitness or recruitment. An inverse relationship between bluegill spawning duration, the number of pulsed spawning events, variability in the distribution, or allocation of eggs and annual variability could exist under different scenarios. A truncated spawning duration, few pulsed spawning events, and less variability in the distribution or allocation of eggs is more likely to occur in years that are more predictable (e.g., fewer predators and competitors). Alternatively, years that are less predictable and more stressful will favor a longer spawning duration to maximize fitness (e.g., bet hedging: more predators and competitors). Schematic and partial concept adopted from Tonn et al. (1990) and Jackson et al. (2001).
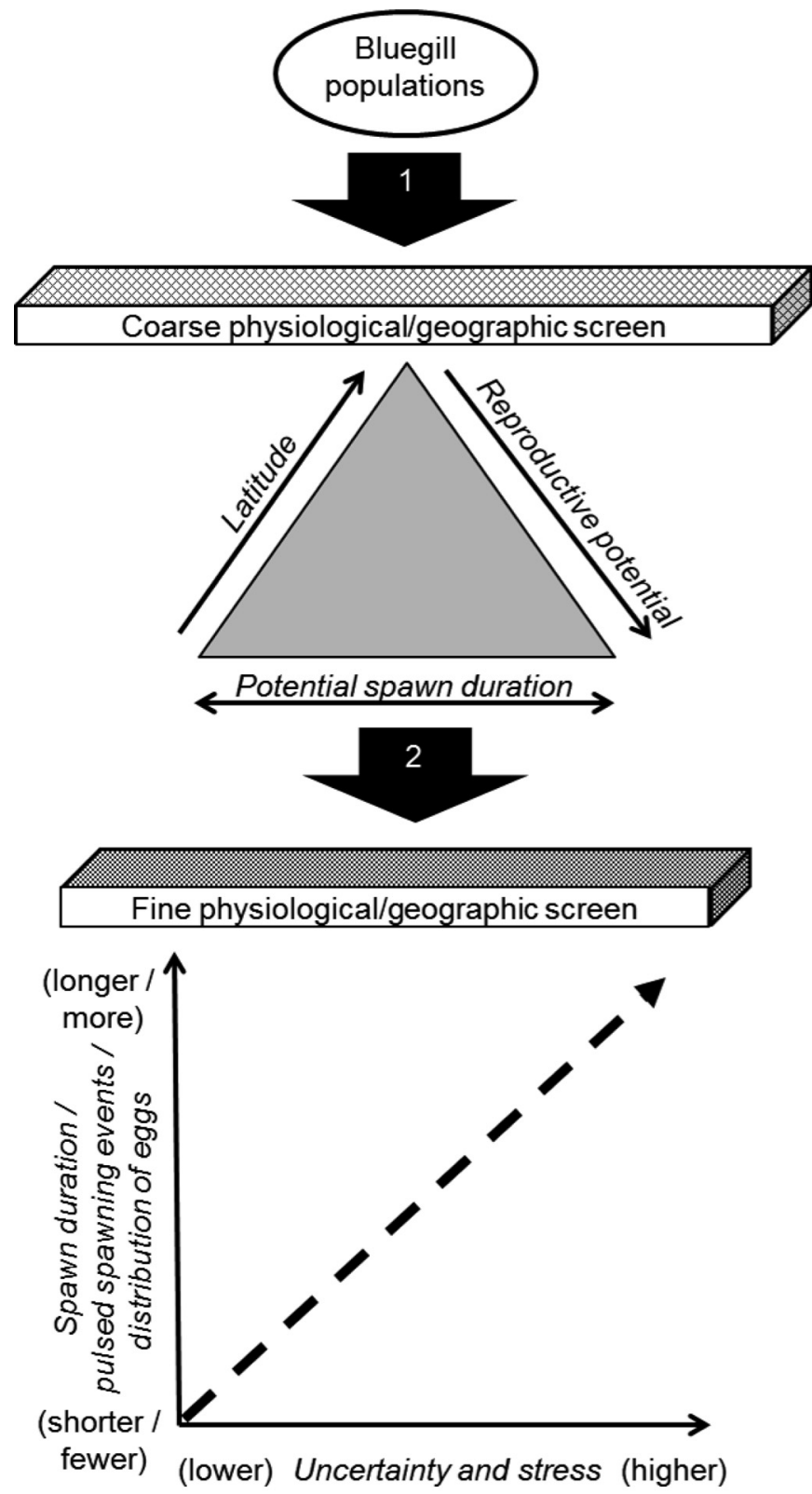

- Published by NRC Research Press 
other northern bluegill populations that can exhibit more than one pulsed spawning event, despite shorter growing seasons (Garvey et al. 2002; Jolley et al. 2009; Table 6).

As with previous bluegill recruitment studies (Beard 1982; Cargnelli and Gross 1996; Partridge and DeVries 1999; Santucci and Wahl 2003; Edwards et al. 2007), we also identified more biotic than abiotic factors shaping recruitment patterns during the first summer of life. Both early and late-hatched larval bluegill growth was influenced to some degree by food availability and interspecific and intraspecific competition, regardless of age class examined (Krumholz 1949; Latta and Merna 1977; Partridge and DeVries 1999). Water transparency, whether physical or biological in nature, and temperature also appeared to be important for larval bluegill growth, depending on hatch period and age class (Garvey et al. 2002). Conversely, we did not find any factors related to juvenile bluegill growth, potentially because of our temporal study design in sampling; zooplankton and benthic macroinvertebrates were not typically sampled in September when juveniles were collected. We also identified positive relationships between larval bluegill growth and water transparency, negative relations between bluegill growth and interspecific competition (yellow perch), and negative relations between larval growth and prey availability. The first two relationships seem intuitive, but growth rates should typically increase as a result of greater food resources. Growth rates were highest during periods when no yellow perch were present and water transparency was high, but food availability was low, potentially a result of zooplankton grazing by larval bluegill, which are visual particulate feeders (Bremigan and Stein 1994). Therefore, some complex interactive relationship seems to exist between water transparency, prey availability, and interspecific competition that ultimately influences growth for larval bluegill in Pelican Lake.

Survival for early-hatched bluegill larvae in Pelican Lake was substantially lower than late-hatched cohorts across all years examined, similar to results from other studies (Garvey et al. 2002; Santucci and Wahl 2003). Lower survival for early-hatched bluegills may be explained in part by slower growth rates experienced due to competition with yellow perch for prey resources compared with late-hatched bluegill. Although we did not find any relation between survival of early hatched bluegills and either of these factors (competition and prey availability), few individuals survived to the fall life stage in any year, which may have obscured our ability to measure or detect such relationships. A majority of the estimated early hatched survival indices were zero $(9$ out of 16, compared with 1 out of 21 for late-hatched cohorts), which may explain why survival was positively related to early hatched age-0 bluegill abundance and further suggesting a major survival bottleneck that can only be accounted for through higher early-hatched larval bluegill production and densities. Kaemingk et al. (2012) found slower growth rates for first-emerging age-0 bluegill (TL, 10.1-25 mm) in Pelican Lake, Nebraska, and attributed this observation to age-0 yellow perch competition for Daphnia. Our study further supports this competition hypothesis, but extends these competitive interactions to earlier life stages for bluegill ( $<10.1 \mathrm{~mm} \mathrm{TL})$. Thus, yellow perch could potentially regulate bluegill recruitment for early hatched cohorts through competition for available prey resources, as evidenced by reduced growth rates at both larval and age-0 life stages (Kaemingk et al. 2012).

The bluegill spawning plasticity hypothesis warrants further investigation across both temporal and spatial dimensions as well as its potential application to other species. Evaluation through common garden experiments may indicate whether this adaptation is genetically or environmentally driven, a similar approach used to evaluate the socially mediated maturity hypothesis within bluegill populations (Aday et al. 2003, 2006). The ability for a species to exhibit a plastic life history strategy would undoubtedly be advantageous for long-term population viability, especially when environments become less predictable and more stressful, resulting in fewer resources for recruitment. This concept and understanding will help to identify and categorize species according to priority and needs in future decisions regarding conservation and management.

\section{Acknowledgements}

We sincerely thank all the technicians who assisted in the field and laboratory, especially A. Andrews for the aging component of this study. M. Lindvall and Valentine National Wildlife Refuge provided access to Pelican Lake. Z. Brashears, D. Graham, D. Hartmann, D. Krueger, and the Valentine State Fish Hatchery provided assistance. Thanks to T.L. Galarowicz for reviewing an earlier draft and providing helpful comments. Funding for this project was provided by the Nebraska Game and Parks Commission through the Federal Aid in Sport Fish Restoration Project F-118-R.

\section{References}

Aday, D.D., Wahl, D.H., and Philipp, D.P. 2003. Assessing population-specific and environmental influences on bluegill life histories: a common garden approach. Ecology, 84(12): 3370-3375. doi:10.1890/02-3139.

Aday, D.D., Philipp, D., and Wahl, D. 2006. Sex-specific life history patterns in bluegill (Lepomis macrochirus): interacting mechanisms influence individual body size. Oecologia, 147(1): 31-38. doi:10.1007/s00442-005-0242-x. PMID: 16163554.

Auer, N.A. 1982. Identification of larval fishes of the Great Lakes basin with emphasis on the Lake Michigan drainage. Special Publication 82-3, Great Lakes Fishery Commission, Ann Arbor, Michigan.

Beard, T.D. 1982. Population dynamics of young-of-the-year bluegill. Technical Bulletin No. 127, Wisconsin Department of Natural Resources, Madison.

Benke, A.C., Huryn, A.D., Smock, L.A., and Wallace, J.B. 1999. Length-mass relationships for freshwater macroinvertebrates in North America with particular reference to the southeastern United States. J. N. Am. Benthol. Soc. 18(3): 308-343. doi:10.2307/1468447.

Bremigan, M.T., and Stein, R.A. 1994. Gape-dependent larval foraging and zooplankton size: implications for fish recruitment across systems. Can. J. Fish. Aquat. Sci. 51(4): 913-922. doi:10.1139/f94-090.

Brown, M.L., and St. Sauver, T. 2002. An assessment of yellow perch, Perca flavescens, stocking contributions in eastern South Dakota lakes. Fish. Manag. Ecol. 9(4): 225-234. doi:10.1046/j.1365-2400.2002.00299.x.

Bunnell, D.B., González, M.J., and Stein, R.A. 2003. Zooplankton biomass enhances growth, but not survival, of first-feeding Pomoxis spp. larvae. Can. J. Fish. Aquat. Sci. 60(11): 1314-1323. doi:10.1139/f03-112.

Burnham, K.P., and Anderson, D.R. 2002. Model selection and multi-model inference: a practical information-theoretic approach. 2nd ed. Springer, New York.

Cargnelli, L.M., and Gross, M.R. 1996. The temporal dimension in fish recruitment: birth date, body size, and size-dependent survival in a sunfish (bluegill: Lepomis macrochirus). Can. J. Fish. Aquat. Sci. 53(2): 360-367. doi:10.1139/f95193.

Chvala, P.J. 2000. Bluegill reproductive characteristics in Nebraska Sandhill lakes. Master's thesis, South Dakota State University, Brookings.

Coble, D.W. 1988. Effects of angling on bluegill populations: management implications. N. Am. J. Fish. Manag. 8(3): 277-283. doi:10.1577/1548-8675(1988) 008<0277:EOAOBP>2.3.CO;2.

Coleman, R.M., Gross, M.R., and Sargent, R.C. 1985. Parental investment decision rules: a test in bluegill sunfish. Behav. Ecol. Sociobiol. 18(1): 59-66. doi:10. 1007/BF00299238.

Culver, D.A., Boucherle, M.M., Bean, D.J., and Fletcher, J.W. 1985. Biomass of freshwater crustacean zooplankton from length-weight regressions. Can. J. Fish. Aquat. Sci. 42(8): 1380-1390. doi:10.1139/f85-173.

Cummins, K.W., and Wuycheck, J.C. 1971. Caloric equivalents for investigations in ecological energetics. Schweizerbart, Stuttgart.

DeBoer, J.A., Pope, K.L., and Koupal, K.D. 2013. Environmental factors regulating the recruitment of walleye Sander vitreus and white bass Morone chrysops in irrigation reservoirs. Ecol. Freshwat. Fish. 22(1): 43-54. doi:10.1111/eff.12000.

DeVries, D.R., and Stein, R.A. 1992. Complex interactions between fish and zooplankton: quantifying the role of an open-water planktivore. Can. J. Fish. Aquat. Sci. 49(6): 1216-1227. doi:10.1139/f92-137.

Dumont, H.J., Van de Velde, I., and Dumont, S. 1975. The dry weight estimate of biomass in a selection of Cladocera, Copepoda and Rotifera from the plankton, periphyton and benthos of continental waters. Oecologia, 19(1): 79-97. doi:10.1007/BF00377592.

Edwards, K.R., Phelps, Q.E., Graeb, B.D.S., and Willis, D.W. 2007. Asynchronous bluegill recruitment in four South Dakota impoundments. J. Freshw. Ecol. 22(1): 19-22. doi:10.1080/02705060.2007.9664141.

Gabelhouse, D.W., Jr. 1987. Responses of largemouth bass and bluegills to removal of surplus largemouth bass from a Kansas pond. N. Am. J. Fish. Manage. 7(1): 81-90. doi:10.1577/1548-8659(1987)7<81:ROLBAB>2.0.CO;2.

Garvey, J.E., and Stein, R.A. 1998. Competition between larval fishes in reser- 
voirs: the role of relative timing of appearance. Trans. Am. Fish. Soc. 127(6): 1021-1039. doi:10.1577/1548-8659(1998)127<1021:CBLFIR>2.0.CO;2.

Garvey, J.E., Herra, T.P., and Leggett, W.C. 2002. Protracted reproduction in sunfish: the temporal dimension in fish recruitment revisited. Ecol. Appl. 12(1): 194-205. doi:10.1890/1051-0761(2002)012[0194:PRISTT]2.0.CO;2.

Gross, M.R., and Sargent, R.C. 1985. The evolution of male and female parental care in fishes. Am. Zool. 25(3): 807-822. doi:10.1093/icb/25.3.807.

Holland-Bartels, L.E., Littlejohn, S.K., and Huston, M.L. 1990. A guide to larval fishes of the Upper Mississippi River. US Fish and Wildife Service, LaCrosse, Wisconsin.

Isermann, D.A., and Willis, D.W. 2008. Emergence of larval yellow perch, Perca flavescens, in South Dakota lakes: potential implications for recruitment. Fish. Manage. Ecol. 15(4): 259-271. doi:10.1111/j.1365-2400.2008.00610.x.

Jackson, D.A., Peres-Neto, P.R., and Olden, J.D. 2001. What controls who is where in freshwater fish communities the roles of biotic, abiotic, and spatial factors. Can. J. Fish. Aquat. Sci. 58(1): 157-170. doi:10.1139/f00-239.

Jolley, J.C., Edwards, K.R., and Willis, D.W. 2009. Bluegill (Lepomis macrochirus) spawning periodicity and hatching duration in the Northern Great Plains, U.S.A. J. Freshwat. Ecol. 24(1): 29-38. doi:10.1080/02705060.2009.9664262.

Jolley, J.C., Willis, D.W., and Holland, R.S. 2010. Match-mismatch regulation for bluegill and yellow perch larvae and their prey in Sandhill lakes. J. Fish. Wildl. Manage. 1(2): 73-85. doi:10.3996/062010-JFWM-018.

Kaemingk, M.A., and Willis, D.W. 2012. Mensurative approach to examine potential interactions between age-0 yellow perch (Perca flavescens) and bluegill (Lepomis macrochirus). Aquat. Ecol. 46(3): 353-362. doi:10.1007/s10452-0129406-z.

Kaemingk, M.A., Jolley, J.C., Willis, D.W., and Graeb, B.D.S. 2011. Exploring spatial distributions of larval yellow perch Perca flavescens, bluegill Lepomis macrochirus and their prey in relation to wind. J. Fish Biol. 78(4): 1132-1151. doi:10.1111/j.1095-8649.2011.02924.x. PMID:21463311.

Kaemingk, M.A., Jolley, J.C., Willis, D.W., and Chipps, S.R. 2012. Priority effects among young-of-the-year fish: reduced growth of bluegill sunfish (Lepomis macrochirus) caused by yellow perch (Perca flavescens)? Freshwat. Biol. 57(4): 654-665. doi:10.1111/j.1365-2427.2011.02728.x.

Kallemeyn, L.W. 1987. Correlations of regulated lake levels and climatic factors with abundance of young-of-the-year walleye and yellow perch in four lakes in Voyageurs National Park. N. Am. J. Fish. Manage. 7(4): 513-521. doi:10.1577| 1548-8659(1987)7<513:CORLLA>2.0.CO;2.

Kim, Y.U., and Park, Y.S. 1987. Development of eggs, larvae and juveniles of bluegill, Lepomis macrochirus Rafinesque. J. Korean Fish. Soc. 20: 24-32.

Krumholz, L.A. 1949. Rates of survival and growth of bluegill yolk fry stocked at different intensities in hatchery ponds. Trans. Am. Fish. Soc. 76(1): 190-203. doi:10.1577/1548-8659(1946)76[190:ROSAGO]2.0.CO;2.

Latta, W.C., and Merna, J.W. 1977. Some factors influencing size of the year class of bluegills (Lepomis macrochirus) in ponds. Michigan Academician, 9: 483502 .

Lind, O.T. 1985. Handbook of common methods of limnology. 2nd ed. Kendall Hunt, Dubuque, Iowa.

Lynch, M., Weider, L.J., and Lampert, W. 1986. Measurement of the carbon balance in Daphnia. Limnol. Oceanogr. 31(1): 17-33. doi:10.4319/1o.1986.31.1. 0017.

McCauley, E., and Kalff, J. 1981. Empirical relationships between phytoplankton and zooplankton biomass in lakes. Can. J. Fish. Aquat. Sci. 38(4): 458-463. doi:10.1139/f81-063.

Olden, J.D., Poff, N.L., and Bestgen, K.R. 2006. Life-history strategies predict fish invasions and extirpations in the Colorado River Basin. Ecol. Monogr. 76(1): 25-40. doi:10.1890/05-0330.

Olson, N.W., Paukert, C.P., Willis, D.W., and Klammer, J.A. 2003. Prey selection and diets of bluegill Lepomis macrochirus with differing population characteristics in two Nebraska natural lakes. Fish. Manage. Ecol. 10(1): 31-40. doi:10. 1046/j.1365-2400.2003.00323.x.

Paine, M.D. 1990. Life history tactics of darters (Percidae: Etheostomatiini) and their relationship with body size, reproductive behaviour, latitude and rarity. J. Fish Biol. 37(3): 473-488. doi:10.1111/j.1095-8649.1990.tb05877.x.
Partridge, D.G., and DeVries, D.R. 1999. Regulation of growth and mortality in larval bluegills: implications for juvenile recruitment. Trans. Am. Fish. Soc. 128(4): 625-638. doi:10.1577/1548-8659(1999)128<0625:ROGAMI>2.0.CO;2.

Paukert, C.P., Willis, D.W., and Holland, R.S. 2002. Sample size requirements for in situ vegetation and substrate classifications in shallow, natural Nebraska lakes. N. Am. J. Fish. Manage. 22(4): 1329-1333. doi:10.1577/1548-8675(2002) 022<1329:SSRFIS >2.0.CO;2.

Philippi, T., and Seger, J. 1989. Hedging one's evolutionary bets, revisited. Trends Ecol. Evol. 4(2): 41-44. doi:10.1016/0169-5347(89)90138-9. PMID:21227310.

Pine, W.E., and Allen, M.S. 2001. Differential growth and survival of weekly age-0 black crappie cohorts in a Florida lake. Trans. Am. Fish. Soc. 130(1): 80-91. doi:10.1577/1548-8659(2001)130<0080:DGASOW>2.0.CO;2.

Rabeni, C. 1996. Invertebrates. In Fisheries Techniques, 2nd ed. Edited by B.R. Murphy and D.W. Willis. American Fisheries Society, Bethesda, Maryland. pp. 335-352.

Reznick, D. 1985. Costs of reproduction: an evaluation of the empirical evidence. Oikos, 44(2): 257-267. doi:10.2307/3544698.

Santucci, V.J., and Wahl, D.H. 2003. The effects of growth, predation, and firstwinter mortality on recruitment of bluegill cohorts. Trans. Am. Fish. Soc. 132(2): 346-360. doi:10.1577/1548-8659(2003)132<0346:TEOGPA>2.0.CO;2.

Schneider, J.C. 1999. Dynamics of quality bluegill populations in two Michigan lakes with dense vegetation. N. Am. J. Fish. Manage. 19(1): 97-109. doi:10.1577| 1548-8675(1999)019<0097:DOQBPI>2.0.CO;2.

SDGFP. 2011. South Dakota statewide fisheries survey, Region 3. South Dakota Department of Game, Fish and Parks, Fisheries Division Report 2102-F-21-R-4 4, Pierre.

Seaburg, K.G., and Moyle, J.B. 1964. Feeding habits, digestive rates, and growth of some Minnesota warmwater fishes. Trans. Am. Fish. Soc. 93(3): 269-285. doi:10.1577/1548-8659(1964)93[269:FHDRAG]2.0.CO;2.

Shoup, D.E., and Wahl, D.H. 2008. The effect of largemouth bass predation on overwinter survival of two size-classes of age-0 bluegills. Trans. Am. Fish. Soc. 137(4): 1063-1071. doi:10.1577/T07-038.1.

Smock, L.A. 1980. Relationships between body size and biomass of aquatic insects. Freshwat. Biol. 10(4): 375-383. doi:10.1111/j.1365-2427.1980.tb01211.x.

Taubert, B.D., and Coble, D.W. 1977. Daily rings in otoliths of three species of Lepomis and Tilapia mossambica. J. Fish. Res. Board Can. 34(3): 332-340. doi:10. 1139/f77-054.

Tonn, W.M., Magnuson, J.J., Rask, M., and Toivonen, J. 1990. Intercontinental comparison of small-lake fish assemblages: the balance between local and regional processes. Am. Midl. Nat. 136(3): 345-375. doi:10.1086/285102.

Van Winkle, W., Rose, K.A., Winemiller, K.O., Deangelis, D.L., Christensen, S.W., Otto, R.G., and Shuter, B.J. 1993. Linking life history theory, environmental setting, and individual-based modeling to compare responses of different fish species to environmental change. Trans. Am. Fish. Soc. 122(3): 459-466. doi:10.1577/1548-8659(1993)122<0459:LLHTES>2.3.CO;2.

Weber, M.J., Dettmers, J.M., and Wahl, D.H. 2011. Growth and survival of age-0 yellow perch across habitats in southwestern Lake Michigan: Early life history in a large freshwater environment. Trans. Am. Fish. Soc. 140(5): 11721185. doi:10.1080/00028487.2011.608605.

Werner, E.E., and Hall, D.J. 1977. Competition and habitat shift in two sunfishes (Centrarchidae). Ecology, 58(4): 869-876. doi:10.2307/1936222.

Werner, E.E., and Hall, D.J. 1979. Foraging efficiency and habitat switching in competing sunfishes. Ecology, 60(2): 256-264. doi:10.2307/1937653.

Winemiller, K.O. 1992. Life-history strategies and the effectiveness of sexual selection. Oikos, 63(2): 318-327. doi:10.2307/3545395.

Winemiller, K.O. 1995. Fish ecology. In Encyclopedia of environmental biology. Vol. 2. Edited by W.A. Nierenberg. Academic Press, San Diego. pp. 49-65.

Winemiller, K.O. 2005. Life history strategies, population regulation, and implications for fisheries management. Can. J. Fish. Aquat. Sci. 62(4): 872-885. doi:10.1139/f05-040.

Winemiller, K.O., and Rose, K.A. 1992. Patterns of life-history diversification in North American fishes: implications for population regulation. Can. J. Fish. Aquat. Sci. 49(10): 2196-2218. doi:10.1139/f92-242. 